Research review paper

\title{
Accumulation of energy reserves in algae: from cell cycles to
}

\section{biotechnological applications}

Milada Vítováa $^{\mathrm{a}, 1}$, Kateřina Bišová ${ }^{\mathrm{a}, 1}$, Shigeyuki Kawano ${ }^{\mathrm{b}}$, Vilém Zachleder ${ }^{\mathrm{a},{ }^{*}}$

${ }^{a}$ Institute of Microbiology, CAS, Centre Algatech, Laboratory of Cell Cycle of Algae, 37981 Třeboň, Czech Republic

${ }^{b}$ University of Tokyo, Chiba 277-8562, Japan

* Corresponding author: Institute of Microbiology, CAS, Centre Algatech, Laboratory of Cell Cycle of Algae, 37981 Třeboň, Czech Republic.

Tel.: +420 384310 480, fax: +420 384310 415, mobile: +420 724342657 .

E-mail address: zachleder@gmail.com or zachleder@alga.cz (V. Zachleder).

${ }^{1}$ These authors contributed equally to this work. 
Keywords:

Algae

Carbon dioxide

Cell cycle

Light intensity

Lipids

Microalgae

Nutrient starvation

Starch

Temperature 


\section{ABSTRACT}

Starch and lipids are key components of algal cells and responsible for buffering variable supplies of energy and carbon that are vital for cell growth and reproduction, particularly DNA replication, nuclear and cellular division. The basic characteristics of energy reserves, their ultrastructure and localization inside the cell, regulation of their synthesis in relation to cell cycle phases, and their control by external factors, including light intensity, temperature, and carbon dioxide are described. Over the last two decades, research in this field has been boosted by possible biotechnological applications of algae for the production of biofuels from energy conserving compounds (bioethanol from starch and biodiesel from lipids). Recent findings on mechanisms that lead to an accumulation of exceptionally high levels of starch and lipids in algae will be summarized in this review. Macroelement $(\mathrm{N}, \mathrm{S}, \mathrm{P})$ limitation, or depletion in mineral medium, as the most widely used approaches for enhancing both starch and lipid accumulation, are reviewed in detail. Potential biotechnological strategies for the economically viable overproduction of lipid and starch, such as a two-step procedure exploiting the effects of nutrient limitation and depletion, as well as the means and rationale for selecting appropriate strains, are discussed. 


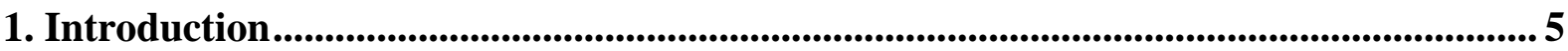

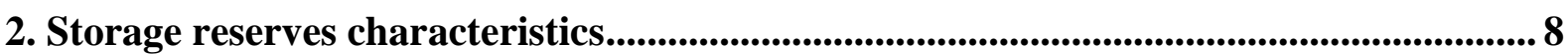

3. Dynamics of energy reserves during the cell cycle...................................................... 11

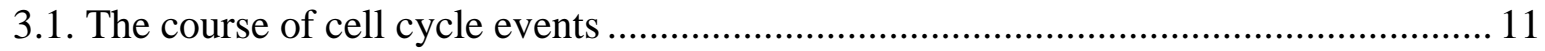

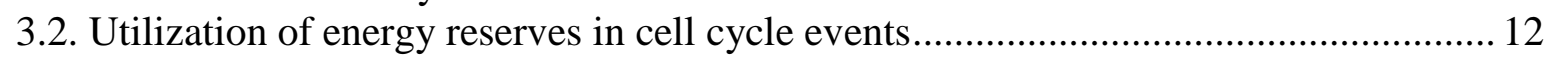

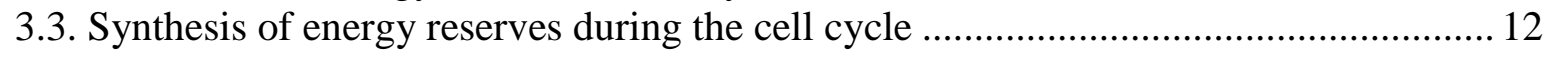

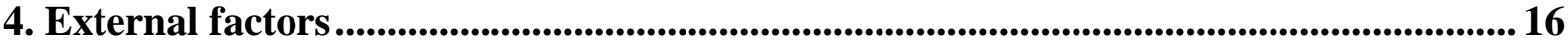

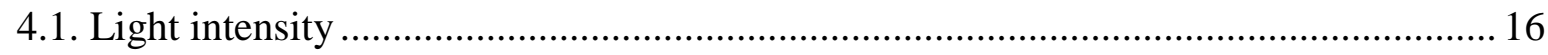

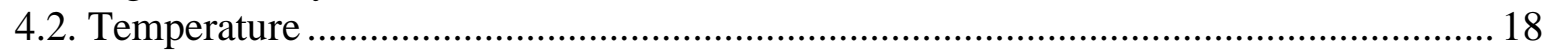

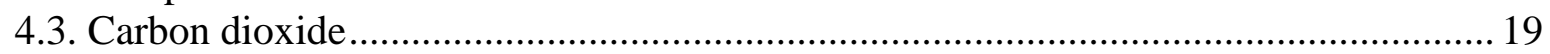

5. Selection of algal species for overproduction of energy reserves in algal suspension .22

6 Approaches to increase accumulation of energy reserves...................................................26

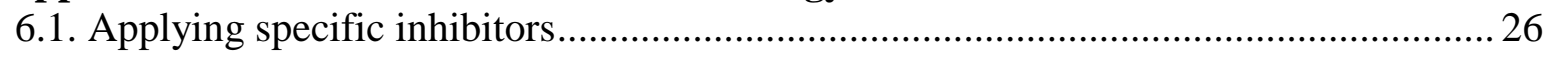

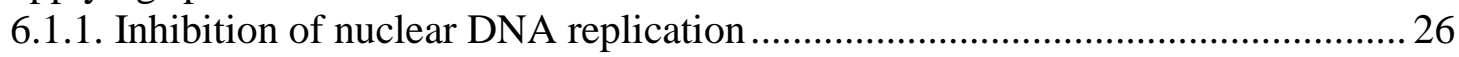

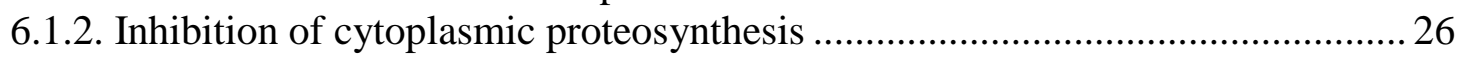

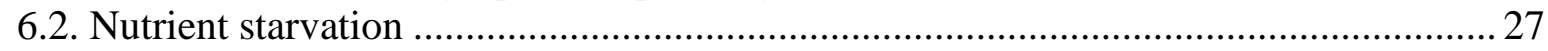

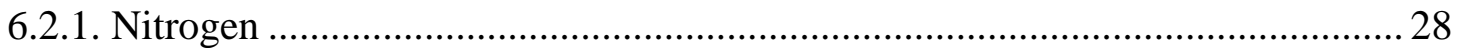

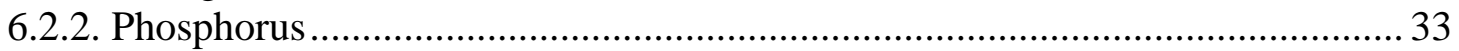

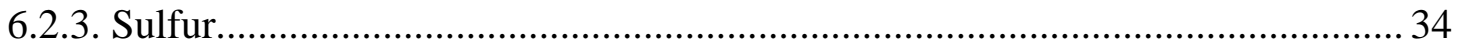

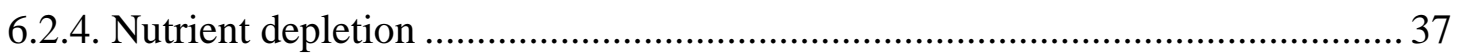

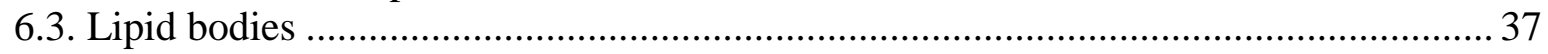

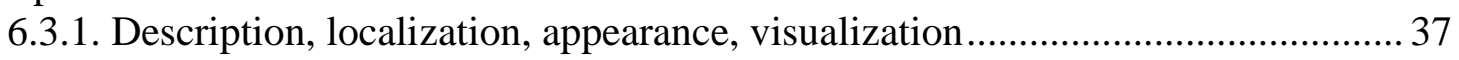

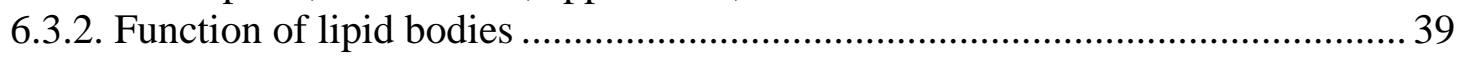

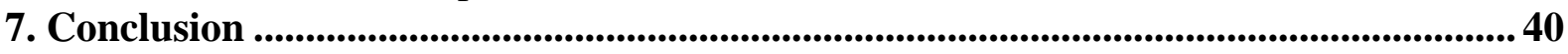

Acknowledgements .........................................................................................................................43

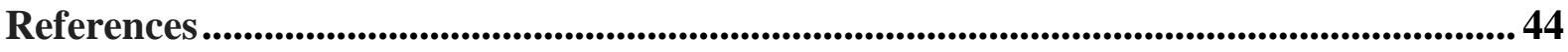




\section{Introduction}

The role of starch energy reserves in the regulation and progression of algal cell cycle has been the subject of basic research since the 1970s (Ballin et al., 1988; Duynstee and Schmidt, 1967; Hirokawa et al., 1982; Klein, 1987; Semenenko and Zvereva, 1972; Šetlík et al., 1988; Zachleder et al., 1988). However, up until about 1990, there was only moderate interest until a recent boost in both basic and applied research in energy reserves. This increased interest was motivated by the view that algae could be a high-yielding source of energy-rich components for bioethanol production from starch (John et al., 2011) and biodiesel production from lipids (Chisti, 2007; Chisti and Yan, 2011; Přibyl et al., 2014; Singh et al., 2011a; Singh et al., 2011b).

To study how starch and lipid reserves are formed and regulated, it is crucial to understand why and where they are produced, how their accumulation can be affected by external growth conditions or genetic manipulation, and what processes or events are involved in their utilization (degradation) within the algal life and cell cycle. For the sake of simplicity, the term starch will be used throughout the manuscript because most of the research was done on green algae producing starch; however, rules similar to these described here for starch will also be generally valid for other polyglucans produced by other algal species (glycogen in cyanobacteria and red algae, chrysolaminarin in diatoms, paramylon in euglenophytes, and floridean starch in red algae).

Both starch and lipid metabolism starts with a common initial pool of molecules consisting of three carbons, such as 3-phosphoglycerate (3PG) and glyceraldehyde 3-phosphate (GAP) (de Jaeger et al., 2014) (Fig. 1). From 28 molecules of 3PG, one molecule of C18 TAG or 14 molecules of glucose in a starch matrix can be formed (de Jaeger et al., 2014). Most algae can produce both starch (or other polyglucans) and lipids as energy 
reserves, with ratios that differ depending on growth conditions. In the most common situation, starch is the primary energy compound but how its production switches to triacylglycerol production (carbon partitioning) under specific conditions is not completely understood. Existing knowledge on the relationship between metabolic pathways influencing starch and reserve lipid accumulation by common C3 precursors is illustrated in Fig. 1. Starch functions as a primary storage of energy, being formed in light, providing energy for key metabolic processes independently of external energy sources (for details, see Section 2) (de Winter et al., 2013). Reserve lipids (TAG), however, usually serve as a secondary energy source and an electron sink when their production is more economical for the cell than production of starch (usually under conditions of nutrient limitation) (Hu et al., 2008).

The production and accumulation of energy rich molecules, like starch and lipids, is an indispensable buffer against varying external growth conditions and allows the photosynthetic cell to survive periods of light-energy absence at night, as well as during periods of varying light intensity. Both compounds serve as a source of energy and carbon and thus not only ensure cell survival but also supply energy for processes related to cell multiplication, such as DNA replication, nuclear division, cytokinesis, and daughter cell formation and liberation.

From a historical point of view, research on microalgae and the application of microalgae as sources of renewable energy covers a span of approximately 140 years. The first report on growing microalgae (diatoms) as a source of lipids for food or fuel, and their large-scale production, was published in 1942 in an effort to substitute for limited sources of fossil fuels during the Second World War (Harder and von Witsch, 1942a; Harder and von Witsch, 1942b). For a more detailed historical tour, we refer readers to a recent excellent overview of the topic Algae for Biofuels and Energy (Borowitzka and Moheimani, 2013). From that time up to now, much effort was dedicated to improving algal biomass growth on a large scale, leading to testing, optimization and production of different bioreactors and cultivation 
regimes for different algal species. However, we feel that the effort was driven by trial and error in many cases and was not backed up by basic research, an approach that may have inhibited further development and improvement. We strongly believe that understanding algal physiology, beyond the simple characteristics of growth, such as biomass increase or photosynthetic efficiency, is essential for improving industrial productivity. The life- and cellcycle stages of algae are of paramount importance for their behavior, and understanding the background of behavior is crucial for efficient manipulation of biomass and, particularly, energy reserve productivity. This present review will attempt to bridge the gap between basic research and its industrial application. The review concentrates on basic research of energy reserve regulation in the algal cell cycle and discusses the possible applications of such knowledge for scaled-up industrial production of high-energy content reserves.

This paper reviews the current state of knowledge of mechanisms that control the synthesis of starch and lipids as well as the relationship between synthesis and events of the cell cycle. The accumulation of energy reserves under optimal conditions will be compared with increased accumulation of starch and lipids after the inhibition of cell cycle progression.

The effect of light, temperature, carbon dioxide, and nutrient stress on the accumulation of energy reserves will be described, and the procedures for obtaining algal cells enriched in starch or lipids will be discussed. The main attention will be focused on the most effective methods and approaches leading to the overproduction of energy reserves, mainly limitation of single macro-elements like nitrogen, sulfur, or phosphorus.

The reviewed species belong mostly to the taxonomic orders Chlorococcales (Chlorella, Scenedesmus) and Volvocales (Chlamydomonas, Dunaliella) of the phylum Chlorophyta green algae, but other biochemically important taxonomic groups, such as red algae (Rhodophyta, diatoms (Heterokontophyta, Baccillariophyceae) and genus Isochrysis 
(Chromophyta, Haptophyceae) will be also reviewed (for detailed information on taxonomic categorization of reviewed algal species, see (van den Hoek et al., 1995).

\section{Storage reserves characteristics}

Polysaccharides used as energy and carbon reserves, are typically homopolysaccharides composed of glucose units (polyglucans). They are species specific and not affected by changes in growth conditions. Starch is the most common type of polyglucan produced by most green algae (as well as higher plants) as a primary store of carbon and energy, and comprises two different $\alpha$-polyglucans, amylose and amylopectin, in different species-dependent ratios. Amylose and amylopectin differ in the degree of branching. Amylose is the linear form of starch whereas amylopectin is the branched one. Other algae produce different types of polyglucans, for example, chrysolaminarin in diatoms (Heterokontophyta, Baccillariophyceae) (Xia et al., 2014), floridean starch and glycogen in red algae (Rhodophyta), and paramylon in Euglenophyta (for detailed review, see (Hildebrand et al., 2013) that, with the exception of glycogen, are B-polyglucans differing in the type of bonds connecting the glucose subunits. Glycogen (a multibranched polysaccharide of glucose, which is similar to amylopectin) is also an energy reserve in prokaryotic cyanobacteria (Cyanophyta), but some cyanobacteria, such as Cyanobacterium sp., Myxosarcina burmensis and Synechococcus sp., produce distinct $\alpha$-polyglucans, which were designated as semi-amylopectin (Nakamura et al., 2005).

Lipids, the other energy and carbon reserves, represent more concentrated stores of metabolic energy than polyglucans. The yield from the complete oxidation of fatty acids is about $9 \mathrm{kcal} \mathrm{g}^{-1}\left(38 \mathrm{~kJ} \mathrm{~g}^{-1}\right)$, in contrast to about $4 \mathrm{kcal} \mathrm{g}^{-1}\left(17 \mathrm{~kJ} \mathrm{~g}^{-1}\right)$ for carbohydrates (Berg et al., 2002). They can be divided into two groups: polar lipids, which are components of cell membranes and organelles, and non-polar or neutral lipids, which serve as the energy reserves. 
The algal lipid structure, biosynthesis, and functions are described in detail by (Harwood and Guschina, 2009). Neutral lipids are accumulated and stored in algal cells in the form of triacylglycerols and their composition, in contrast to polyglucans, is much more variable. Triacylglycerols consist of glycerol, esterified with three fatty acids in different combinations, which can be saturated or unsaturated. Chain lengths of the fatty acids can vary in length (usually 16, 18 and 20 carbons) and in saturation (saturated, monounsaturated and polyunsaturated).

Oleaginous algae (Eustigmatophyceae Nannochloropsis, Trachydiscus) is the only algal group apparently unable to produce polyglucans (Hildebrand et al., 2013). Diatoms (Bacillariophyceae) have a higher efficiency of nitrogen assimilation from catabolic processes thanks to a unique metabolic feature, the urea cycle (Allen et al., 2011), and are prominent lipid producers, especially under nutrient limitation (Adams and Bugbee, 2014; Yang et al., 2013). Indeed, the marine diatom Odontella aurita is used industrially to produce omega-3fatty acids. The same species also produces ß-polyglucan chrysolaminarin (Xia et al., 2014). For more information on this topic, we refer to recent excellent reviews by Hildenrand et al. (Hildebrand et al., 2013; Hildebrand et al., 2012). Most green algae (Chlorophyta) produce and accumulate starch as a primary energy and carbon reserve, whereas lipids serve as a secondary store produced in minute amounts under standard conditions. The newly formed starch grains are located in chloroplasts, whereas lipids are located in the cytoplasm but can also be found in small amounts in chloroplasts. The primary energy and carbon stores in the form of starch ensure that they are always available for important metabolic processes, independent of immediate energy and that they can supply carbon through photosynthesis (e.g. in darkness or in fluctuating light). Starch's most critical role is to provide energy for cell cycle processes such as DNA replication, nuclear and cellular division; for this purpose, they 
are preferentially used even when photosynthesis is active (Vítová et al., 2011b) (see Section 5).

The synthesis of starch is dependent on photosynthetic activity and is thus affected by variations in light intensity, $\mathrm{CO}_{2}$ supply, and temperature, which will therefore affect the entire cellular metabolism (see Section 4 External factors). Because the primary energy stores are continuously made and spent during cell growth, only the net production of starch is monitored, which represents the sum of totally synthesized starch minus starch continuously degraded during cell growth, through respiration and by the reproductive processes of the cell cycle (DNA replication, nuclear division, protoplast fission, and daughter cell formation).

For the overproduction of both starch and lipids, treatment must ensure that the main cellular energy and carbon utilizing processes in the cytosolic compartment (DNA replication, nuclear division and cellular division) are suppressed, while activities in the chloroplast compartment remain unaffected (see Section 6). During overproduction, some algae preferentially overproduce starch; they are sometimes called "starch" algae, whereas "lipid" algae overproduce lipids (Semenenko et al., 1969; Semenenko et al., 1967; Zukova et al., 1969). Clearly, the ability to overproduce starch or lipids is not limited to distinct taxonomic groups but is widespread and crosses both species and family boundaries. Depending on the conditions, some strains of Chlorella or Parachlorella can overproduce starch (Brányiková et al., 2011), whereas other strains of the same species overproduce lipids instead (Li et al., 2013). Moreover, mutants can be isolated from what were originally "starch" alga, such as Chlamydomonas reinhardtii, but are unable to produce starch, producing lipids as a reserve instead (Goodenough et al., 2014; Li et al., 2010a; Li et al., 2010b; Siaut et al., 2011; Wang et al., 2009; Work et al., 2010; Zabawinski et al., 2001). Usually, strains that overproduce starch in response to stress can synthesize lipids in a small amount but do not overproduce them. In the case of overproduction of lipids, starch is often synthesized at the beginning of 
treatment, whereas lipids start to accumulate much later. Even in cells enriched in lipids, starch remains in small but significant amounts in cells, particularly as grains around pyrenoids. Stress treatments, for example, nutrient limitation or depletion, are the most widely used approaches to overproduce starch and lipids. Such treatments efficiently block further cell cycle progression, not only preventing consumption of the majority of energy reserves but simultaneously stress the cells. Under such conditions, lipids are often produced as an energetically more compact storage pool, yet they also serve as an electron sink preventing the over-reduction of photosynthetic electron transport chain (Breuer et al., 2014). Starch, even when overproduced or accumulated, will be of the same structure as under standard conditions. In contrast, the composition of lipid reserves not only differs substantially in different species or strains but also can vary depending on growth conditions (temperature or other environmental factors, type of stress, for example). Based on fatty acid composition, lipid-enriched algal biomass can be utilized for the production of biodiesel, as food and feed additives, or in pharmaceutical applications.

\section{Dynamics of energy reserves during the cell cycle}

\subsection{The course of cell cycle events}

The cell cycle of chlorococcal algae, particularly those dividing by multiple fission, was described in detail (Přibyl et al., 2013; Šetlík et al., 1972; Šetlík and Zachleder, 1984; Zachleder and Šetlík, 1990) and recently reviewed (Bišová and Zachleder, 2014). In summary, the multiple-fission algal cell cycle is composed of several consecutive steps consisting of growth, DNA replication, nuclear division and cellular division, with the preparative phases preceding each step. The cells dividing into two daughter cells (binary fission) pass through only one growth and reproductive sequence (e.g., DNA replication, nuclear division and 
cellular division) within one cell cycle. After completing a certain amount of synthetic work enabling accumulation of energy and material reserves, the cell attains the "commitment point" which "empowers" it to undergo and terminate DNA replication, nuclear and cellular division without an external energy supply; ie, the cell can divide in the dark (Šetlík et al., 1972). In cases where the cells divide by multiple fission into more than two daughter cells (in general $2^{\mathrm{n}}$, where $\mathrm{n}$ is an integer), several (n) reproductive sequences, mutually overlapping each other, are performed within one cell cycle to terminate in multiple cellular divisions.

\subsection{Utilization of energy reserves in cell cycle events}

In autotrophically growing algae, light energy for photosynthesis is essential for completion of the growth steps during which energy reserves (polyglucans, lipids) accumulate. Consequently, DNA replication, nuclear and cellular division use the reserves to meet their carbon and energy requirements. Interestingly, they do so even when photosynthesis is active (Vítová et al., 2011b), and individual steps of the reproductive sequence proceed, leading to the completion of cell cycles without any external carbon or energy supply, for example, at low light intensity or in the dark (Bišová and Zachleder, 2014;

Šetlík et al., 1972; Šetlík and Zachleder, 1984; Vítová and Zachleder, 2005; Zachleder and Šetlík, 1988; Zachleder and Šetlík, 1990; Zachleder and van den Ende, 1992).

\subsection{Synthesis of energy reserves during the cell cycle}

The time course of starch accumulation during the cell cycle was described in several synchronized cultures of green algae, for example, Chlorella pyrenoidosa (Duynstee and Schmidt, 1967), Chlorella ellipsoidea (Hirokawa et al., 1982), Chlorella vulgaris 
(Brányiková et al., 2011), Scenedesmus quadricauda (Ballin et al., 1988; Šetlík et al., 1988; Zachleder et al., 1988), and Chlamydomonas reinhardtii (Klein, 1987; Vítová et al., 2011b). In all cases, the rules for starch accumulation are almost the same. The dark-born daughter cells at the beginning of the cell cycle had very low starch content. Starch started to accumulate rapidly upon illumination until the content was sufficient to cover the energy and carbon requirement for DNA replication, nuclear and cellular division; starch is apparently one of the prerequisites to attain a commitment point. Starch content decreased dramatically during nuclear and cellular division, even in light grown cells, to accommodate the energy consumption (Vítová et al., 2011b). Moreover, starch is also used to cover all energy requirements in the dark.

Degradation of starch during nuclear and cellular divisions was observed microscopically (Murakami et al., 1963) and by chemical analysis (Cole et al., 1998; Curnutt and Schmidt, 1964; Herrmann and Schmidt, 1965; Johnson and Schmidt, 1966; Schmidt, 1966; Vítová et al., 2011b). During starch degradation, increased activity of starch degrading enzymes occurred (Levi and Gibbs, 1984; Wanka et al., 1970). Due to reconstruction of the chloroplast during its division, photosynthetic rate was markedly decreased, as observed in Chlorella pyrenoidosa (Sorokin, 1957) and Scenedesmus quadricauda (Berková et al., 1972). Concomitant with cessation of photosynthesis, the endogenous respiratory rate accelerated during the onset of nuclear division (Curnutt and Schmidt, 1964). In phototrophically grown algae, starch accumulates during the cell cycle prior to the period of nuclear and cellular division and is utilized as a carbon and energy reserve to ensure that all division processes are independent of varying supplies of carbon and energy. In photoautotrophic prokaryotic cyanobacteria, organic carbon is stored in the form of glycogen instead of starch, but similar to eukaryotic algae, it is produced in the light via photosynthesis. In darkness, organic carbon is degraded in at least two species: Crocosphaera watsonii (Dron et al., 2012; Dron et al., 
2013) and Cyanothece sp. (Červený et al., 2013). In both species, glycogen degradation in the dark by respiration leads to decreased oxygen levels, which is a prerequisite for nitrogen fixation, a unique feature of cyanobacteria. The cells are able to fix carbon dioxide, form glycogen, and release oxygen in the light, whereas in darkness the oxygen and glycogen are consumed and nitrogen is fixed instead. The mechanisms governing such fascinating changes in cell physiology are not clear but are a matter of interest for both basic research and industrial applications because nitrogenases, enzymes responsible for nitrogen fixation, can also fix hydrogen. In such cells, glycogen is not only used to support processes of DNA replication and cell division but also exploited by enormously energy-demanding nitrogen fixation mechanisms.

The level of energy reserves is not the sole requirement for cell division. Nutrient limitation by cultivation in diluted mineral medium in Parachlorella kessleri leads to the accumulation of high levels of lipids, while the cells also maintained a certain content of starch. The cells stopped growth and did not divide once the medium was completely depleted, even though they clearly had sufficient energy reserves to perform reproduction. Only after transfer into a complete mineral medium were they able to grow into large mother cells and subsequently divide more or less synchronously while expending all energy and carbon reserves (both starch and lipids) (Fernandes et al., 2013). The same mechanism is at work in other algae such as Chlamydomonas reinhardtii and Chlorella vulgaris. Growth blockage due to nutrient limitation, is readily overcome by fragmentation of lipid bodies and a decrease in lipid and starch content once the cells are re-supplemented with complete medium (Siaut et al., 2011). The process can occur even in the dark (Přibyl et al., 2013) suggesting the cells were limited by nutrients rather than by the absence of energy reserves, and once the nutrient limitation is lifted, the high levels of storage compounds that 
accumulated during nutrient starvation can serve as an exclusive source of energy and carbon for recovery of growth and reproductive processes.

Most starch analyses during algal cell cycles record only the net content of starch, the sum of starch that was synthesized minus that which was utilized. It is apparent that net accumulation data underestimate the value of actual starch synthesized during the cell cycle. This was clearly demonstrated in Chlamydomonas reinhardtii, where starch content increased at the beginning and at the end of the light period while it decreased in the middle of the light period and in the dark. Labeled bicarbonate was, however, incorporated into starch even at times when the total intracellular level of starch was decreasing, which indicated that the rate of synthesis and degradation can be different but both processes can run simultaneously (Klein, 1987).

The aim of any biotechnological application is to produce biomass with a maximal content of starch or lipid. As a matter of course, growth conditions, particularly light intensity, should be kept at optimal values because starch content increases with light intensity (Brányiková et al., 2011; Šetlík et al., 1972; Zachleder and Brányiková, 2014). It is relatively simple to manage optimal conditions in laboratory settings. Under natural conditions in scaled-up industrial photobioreactors, it is more complicated; the desire to attain optimal conditions has been the main bottleneck for the inexpensive production of starch- or lipidenriched algal biomass. To economically produce starch or lipids from algae, the following conditions should be optimized: intensive sunlight for most of the year, sufficient sources of water, free or inexpensive sources of carbon dioxide and fertilizers. From this point of view, there is only a very limited number of locations that fulfill all of these requirements, and most of the sites used provide only some of the conditions. Sufficient light intensity can be found in subtropical areas, such as Southern Europe or North Africa and similar regions, where the sunlight together with optimal temperature is available for most of the year (Doucha and 
Lívanský, 2006; Rodolfi et al., 2009). Inexpensive or free-of-charge $\mathrm{CO}_{2}$ can be supplied by fuel gas from different industrial sources, such as incinerators (Douskova et al., 2009), biogas plants (Doušková et al., 2010), burning natural gas (Doucha et al., 2005), or lime or cement works. Similarly, fertilizers can be obtained from waste water. However, to avoid increasing the price of such "wastes" by transporting them, the bioreactor needs to be placed close to the waste production sites. Using nutrient limitation, approaches for energy rich storage accumulation could be an easier or more efficient approach for energy rich storage accumulation (see subsection 6.2. Nutrient starvation).

It also should be kept in mind that even under optimal light conditions, , during the night, the cultures usually degrade all or most of the reserves accumulated during the day; this is the main problem. Consequently, even under optimal growth conditions, the only way to attain maximal energy reserves is to minimize those cellular activities that utilize reserves as a source of carbon or energy, particularly during the night in outdoor bioreactors. This stems from the fact that during the cell cycle, nuclear and cellular division processes are the greatest consumers of energy reserves and these processes must be blocked without disturbing the synthesis of starch and other energy reserves. The following sections will deal with this problem in detail.

\section{External factors}

\subsection{Light intensity}

There has been unequivocal agreement in the literature since the 1970s that the synthesis and accumulation of starch increases with increasing light intensity (Brányiková et al., 2011; Hirokawa et al., 1982; Sukenik, 1991; Šetlík et al., 1972; Yao et al., 2012). Under high light intensity ( $\geqq 180 \mu \mathrm{mol}$ photons $\mathrm{s}^{-1} \mathrm{~m}^{-2}$ ) with $2.5 \% \mathrm{CO}_{2}$ aeration, the total amount of carbohydrates (e.g., both starch and structural carbohydrates) can reach up to about $73-80 \%$ 
of dry weight (DW) (Ho et al., 2011). Sufficient light intensity is also crucial for overproduction of lipids (Khotimchenko and Yakovleva, 2005). In marine red alga Tichocarpus crinitus at low light intensities, only membrane lipids and unsaturated fatty acids were increased, whereas at high light intensities, storage lipids increased more than 1.5 fold, together with an increase in the concentration of saturated fatty acids (Khotimchenko and Yakovleva, 2005). Oleaginous alga Nannochloropsis sp. produced the highest amount of lipids (47\% of DW) at the highest temperature used (700 $\mu \mathrm{mol}$ photons s$\left.{ }^{-1} \mathrm{~m}^{-2}\right)(\mathrm{Pal}$ et al., 2011). Eight algal strains, (Chlorella viscosa, C. vulgaris, C. sorokiniana, C. emersonii, Parachlorella beijerinckii, P. kessleri CCALA255, NIES-2159, and NIES-2152), increased starch and lipid productivity under high light intensity $\left(600 \mu \mathrm{mol}\right.$ photons $\left.\mathrm{m}^{-2} \mathrm{~s}^{-1}\right)$ (Takeshita et al., 2014). For Scenedesmus obliquus, the maximal yield of reserve lipids was observed at $\mathrm{pH} 7,27.5^{\circ} \mathrm{C}$ and a high incident light intensity of $200 \mu \mathrm{mol}$ photons s${ }^{-1} \mathrm{~m}^{-2}$. Suboptimal $\mathrm{pH}$ and temperatures reduced both lipid content and yield. A further increase in light intensity resulted in the same TAG content but lower yields (Breuer et al., 2013). The positive effect of increasing light intensity on the accumulation of starch and lipids functions only up to a point, usually equal to saturation of photosynthesis under the given conditions in a particular algal species. At very high light intensities above saturation level, photoinhibition occurs, leading to the cessation of starch synthesis (Ho et al., 2011; Yao et al., 2012) and lower TAG yields (Breuer et al., 2013). Preventing photoinhibition by the accumulation of lipid bodies associated with carotenoids is described by Solovchenko (2012); see also Subsection 6.3.2 (Function of lipid bodies). At very low light intensities below the compensation point or in darkness, both starch and lipid syntheses are stopped and reserves are rapidly degraded.

The effect of light intensity is also strongly dependent on the phase of the cell cycle. It was shown in Chlorella ellipsoidea (Hirokawa et al., 1982), Chlorella vulgaris (Brányiková et al., 2011), and the marine green alga Tetraselmis subcordiformis (Yao et al., 2012) that at 
the end of the cell cycle, starch content decreased rapidly, independent of the light. In Chlorella vulgaris, a maximum starch content of $46 \%$ of DW was attained just prior to the first cell division and decreased during cell division to $13 \%$ of $\mathrm{DW}$, even in cells grown in the light (Brányiková et al., 2011). Besides light intensity, the illumination regime also plays a significant role in regulating starch and lipid accumulation, as previously mentioned. In Chlorella vulgaris, the daily net starch content was degraded during the dark period, and starch levels oscillated during light and dark periods between $10 \%$ and $20 \%$ of DW (Brányiková et al., 2011). The degradation of starch during the dark can be prevented by using starvation treatments targeting nutrients such as sulfur, that inhibit division processes (Brányiková et al., 2011).

Unfortunately, the light intensity data often cited in the literature mostly represents incident light intensities at the surface of bioreactors, whereas the actual, often variable, absorbed mean light intensity (the difference between incident and transmitted light intensities) is not considered. The two values are closed at a low cell concentration, where only slight shadowing by cells occurs. In contrast, they differ significantly, particularly in batch cultures, with increasing cell density. Therefore, the mean light intensity decreases markedly despite the fact that incident light intensity remains constant. For example, in a given batch culture of Chlorella vulgaris illuminated by a constant incident light intensity of $780 \mu \mathrm{mol}$ photons s${ }^{-1} \mathrm{~m}^{-2}$, the mean light intensity of $410 \mu \mathrm{mol}$ photons s${ }^{-1} \mathrm{~m}^{-2}$ decreased to $170 \mu \mathrm{mol}$ photons $\mathrm{s}^{-1} \mathrm{~m}^{-2}$ at the end of the second cell cycle. This was concomitant with a gradual decrease in the content of accumulated starch caused by the decreasing mean light intensity as culture density increased (Brányiková et al., 2011).

\subsection{Temperature}


Similar to the effect of light intensity, the rates of biomass growth as well as lipid and starch accumulation increased to a certain extent with increasing temperature. The optimal temperature at which the highest biomass concentration and the highest biomass productivity are attained, differs among species. The alga Nannochloropsis oculata (Eustigmatophycae) and Chlorella vulgaris (Chlorophyceae) produced maximum lipid yields at $25^{\circ} \mathrm{C}$. Decreasing the temperature caused a decrease in lipid content (Converti et al., 2009). The optimal temperature for lipid production in Scenedesmus sp. (Chlorophyta) was $20{ }^{\circ} \mathrm{C}$ (Li et al., 2011). In Scenedesmus obliquus, the final lipid store content varied between $18 \%$ and $40 \%$ of DW at temperatures between $20^{\circ} \mathrm{C}$ and $27.5^{\circ} \mathrm{C}$. In general, storage starch and lipids are synthesized at all temperatures in the suboptimal range, but the final lipid or starch content is highest at the optimal temperatures favored for biomass growth (Breuer et al., 2013; Gigova et al., 2012; Roleda et al., 2013).

However, there are some apparent exceptions to this rule. Increasing temperature to a sublethal value $\left(38{ }^{\circ} \mathrm{C}\right)$ caused an increase in lipid content (up to $34 \% \mathrm{DW}$ ) in Nannochloropsis oculata and Chlorella vulgaris (Converti et al., 2009). It should be kept in mind that there are multiple parameters affecting growth, and the cells will respond primarily to the most limiting or even stressful parameter. Sub-lethal temperatures and macroelement starvation not only affect cell growth (Liu et al., 2012) but also block division (see Section 6) (Breuer et al., 2013). Therefore, the cell response is no longer responding simply to light intensity or temperature. Under stress conditions, the production of energy reserves operates as an energy sink (safety valve) against over-excitation when the energy cannot be used for protein whose synthesis is limited by a lack of nitrogen, phosphorus, or sulfur (Solovchenko, 2012).

\subsection{Carbon dioxide}


In phototrophically grown algae, carbon dioxide ensures the supply of photosynthetic carbon for cell growth. Optimal growth of cultures requires sufficient dissolved $\mathrm{CO}_{2}$, which should be orders of magnitude higher than in air. The increased $\mathrm{CO}_{2}$ requirements are commonly ensured using an aeration gas mixture with a high content of $\mathrm{CO}_{2}$ (usually about $2 \%(\mathrm{v} / \mathrm{v}$ ) $\mathrm{CO}_{2}$ is applied). Aeration with pure air caused a decrease in growth of Parachlorella kessleri (Li et al., 2013). Interestingly, even when growth rate was decreased by other factors, such as under conditions of nutrient limitation by depleting mineral medium, rates of lipid accumulation were decreased by $\mathrm{CO}_{2}$ limitation (Li et al., 2013) suggesting that the amount of carbon dioxide in air is not sufficient even under such conditions. The concentration of $\mathrm{CO}_{2}$ in the aeration mixture did not affect the final content of accumulated lipid reserves only when growth ceased completely (Li et al., 2013). Similar results were also found for other organisms and energy reserves. $C$. reinhardtii grew rapidly with $5 \% \mathrm{CO}_{2}$ under nitrogen limitation and quickly accumulated starch, which was followed by accumulation of TAG. The low $\mathrm{CO}_{2}$ cultures exhibited carbon limitation and slow metabolic growth with minimal TAG or starch accumulation (Gardner et al., 2013).

The starch content of the marine alga, Tetraselmis subcordiformis, was low (17.76\%) at low $\mathrm{CO}_{2}$ supply but increased after supplying higher concentrations of $\mathrm{CO}_{2}$ (Zheng et al., 2011). The higher concentration of $\mathrm{CO}_{2}$ also affected the rate of starch hydrolysis, which caused changes in the amylose to amylopectin ratio at higher $\mathrm{CO}_{2}$ concentrations (Tanadul et al., 2014).

For scale-up production of algal biomass, an increased supply of $\mathrm{CO}_{2}$ represents an increase in biomass cost. The only way to maintain production costs for algal biomass at an elevated $\mathrm{CO}_{2}$ concentration is to use cheap or free sources of $\mathrm{CO}_{2}$, such as flue gases from biogas plants, incinerators of domestic or other organic waste, lime works, cement works, or power stations (Brennan and Owende, 2010). The production of algal biomass was 
successfully tested using flue gas generated by burning natural gas (Doucha et al., 2005) derived from the incineration of municipal waste (Douskova et al., 2009); a cogeneration unit provided flue gas by the burning of biogas (Kaštánek et al., 2010). It is advantageous that microalgae can utilize $\mathrm{CO}_{2}$ at high concentrations because its content in flue gases is usually very high. Flue gases can contain about $13 \% \mathrm{CO}_{2}$ (Doušková et al., 2010), but Chlorella could even grow on biogas from anaerobic digestion, that is, a gas mixture containing methane and about $40 \%$ of $\mathrm{CO}_{2}$ and no oxygen (Doušková et al., 2010). In addition to producing cheaper biomass, utilizing waste $\mathrm{CO}_{2}$ is an environmentally effective method for the bioremediation of $\mathrm{CO}_{2}$ (Douskova et al., 2009; Doušková et al., 2010; Kaštánek et al., 2010); for review, see (Brennan and Owende, 2010). The apparent tolerance of algae to high $\mathrm{CO}_{2}$ is also affected by limited dissolution of $\mathrm{CO}_{2}$ gas in the medium. Thus, even at a higher $\mathrm{CO}_{2}$ concentration, only a limited amount of $\mathrm{CO}_{2}$ is dissolved in medium and available for algal growth (details see below); the rest of the $\mathrm{CO}_{2}$ could not be utilized and remained in the outgoing gas mixture. This is nicely shown by the effect of different $\mathrm{CO}_{2}$ concentrations (from $5 \%$ to $50 \%(\mathrm{v} / \mathrm{v})$ ) on the growth of the green alga, Chlorococcum littorale, where the highest lipid content under nitrogen starvation was found at a concentration of $5 \% \mathrm{CO}_{2}(\mathrm{Ota}$ et al., 2009).

In most papers, only concentrations of $\mathrm{CO}_{2}$ in external sources (aeration mixtures, biogas, or flue gas mixtures) are given, whereas the content of dissolved $\mathrm{CO}_{2}$ is not known, which is understandable because determining the concentration of dissolved $\mathrm{CO}_{2}$ acceptable for the growth of algal cells is complicated. Firstly, at a constant partial pressure of carbon dioxide in the atmosphere, solubility of $\mathrm{CO}_{2}$ varies markedly depending on the temperature of the algal suspension. Secondly, $\mathrm{CO}_{2}$ in water can be present in three forms carbonic acid $\left(\mathrm{H}_{2} \mathrm{CO}_{3}\right)$ formed by dissolving of $\mathrm{CO}_{2}$ and the products of its dissociation, bicarbonate $\mathrm{HCO}_{3}{ }^{-}$ and carbonate $\mathrm{CO}_{3}{ }^{-}$anions. The ratio of the three forms is $\mathrm{pH}$ dependent. From these three 
forms, the bicarbonate anion $\left(\mathrm{HCO}_{3}{ }^{-}\right)$is the most important for growth of algae, and whose maximum dissociation is in the $\mathrm{pH}$ range from 7 to 9 . Thirdly, in the presence of $\mathrm{Ca}$ and $\mathrm{Mg}$ ions in the nutrient medium, insoluble carbonates can be formed, particularly at a higher $\mathrm{pH}$, and this decreases the level of anions available for growth (Reid et al., 1987).

Because it is so complex to detect dissolved forms of $\mathrm{CO}_{2}$, researchers chose a more practical empirical approach to determine the concentration of external $\mathrm{CO}_{2}$ in air mixtures, and use it to prevent growth limitation at a given light and temperature. For example, cultures of Parachlorella kessleri growing in complete mineral medium required higher $\mathrm{CO}_{2}$ concentrations because aeration with pure air $\left(0.03 \%\right.$ of $\left.\mathrm{CO}_{2}\right)$ caused both decreased biomass and storage lipid accumulation ( $\mathrm{Li}$ et al., 2013). The same culture, grown slowly in 10-fold diluted mineral medium, showed no difference if aerated by pure air or air supplemented with $2 \%$ of $\mathrm{CO}_{2}$ (Li et al., 2013), which suggests that simple growth is not the only parameter that should be monitored during optimization.

\section{Selection of algal species for overproduction of energy reserves in algal suspension}

The selection of appropriate algal species or strains is the first and most important step when aiming for production of starch- or lipid-enriched algal biomass. A high growth rate of algal cultures, particularly for open air bioreactors, is an important selection criterion to prevent contamination by faster growing species. Algal species such as Chlorella, Parachlorella, and Chlamydomonas usually fulfill this condition and have the ability to produce large amounts of starch. Maximum starch production, including highest productivity, is usually tightly coupled with optimal growth conditions (appropriate light intensity, temperature, and $\mathrm{CO}_{2}$ supply) (see Section 4 External factors). As mentioned above, starch production, which is of interest in any scaled-up industrial process, is measured as net 
production, that is, the total production of starch minus starch consumed in darkness and that is spent by enormous consuming activities such as nuclear and cellular divisions. To increase net starch production as much as possible, processes and activities consuming energy and carbon from starch must by minimized or stopped completely. Various treatments leading to the overproduction of starch reserves in the form of chloroplastic starch grains (net starch synthesis) are described in Section 6, 'Approaches to increase accumulation of energy reserves'.

The oleaginous algae Eustigmatophyceae (Nannochloropsis and Trachydiscus) produce lipids exclusively as an energy reserve and therefore must be omitted as starch producers. This also applies, to some extent, to diatoms, in which production of polyglucans is scarce (Xia et al., 2014). Most green algae produce both starch and oil but in different amounts and different ratios (Breuer et al., 2012; Fernandes et al., 2013; Mizuno et al., 2013; Takeshita et al., 2014; Vigeolas et al., 2012). Strains can differ even within a single species. In some strains (e.g., Parachlorella kessleri, and some strains of Chlorella), oil production is inducible (Fernandes et al., 2013; Li et al., 2013; Přibyl et al., 2013), whereas in others (e.g., some strains of Chlorella, Tetraselmis, and Chlamydomonas), starch production is inducible. This phenomenon is complex because both types of species or strains, under standard environmental conditions in complete nutrient medium, produce both types of reserves. Starch grains produced in chloroplasts are the primary source of energy, whereas small amounts of lipid occur as lipid bodies in both chloroplasts and the cytoplasm. In all species, starch intensively accumulates shortly after the beginning of nitrogen starvation or other stress treatments, whereas storage lipid accumulation starts within a few hour to days later (Breuer et al., 2012; Fernandes et al., 2013; Ho et al., 2011; Lacour et al., 2012; Mizuno et al., 2013; Siaut et al., 2011; Takeshita et al., 2014). The particular dynamics of starch and lipid accumulation, and ratios of compounds, depends both on the species and the type of induction. 
In nitrogen deficient Chlamydomonas reinhardtii, starch initially increased, but then declined whilst lipids started to accumulate later than starch, and continued to high levels (Siaut et al., 2011). In contrast, in oleaginous species like Scenedesmus obliquus, the rate of lipid productions as well as the final lipid content under similar treatment was much higher (Breuer et al., 2012). In Parachlorella kessleri, where depletion of medium was used as a stress treatment, starch accumulated rapidly within the first day, and then slowly decreased to a relatively low level. Accumulation of lipids started one or two days later but was slower, and the final lipid content was much higher than that of starch (Fernandes et al., 2013). This trend was nicely evidenced by comparison of lipid and starch accumulation in different strains and species of algae under nitrogen (Breuer et al., 2012) or sulfur (Takeshita et al., 2014) starvation. Individual species and strains differed in their maximum content of accumulated starch. After the peak of starch accumulation (Breuer et al., 2012; Takeshita et al., 2014), starch storage tended to decrease in most strains, with one exception, Dunaliella tertiolecta. Lipid accumulation started later than starch but increased rapidly during the period when starch was continuously degraded (Breuer et al., 2012; Takeshita et al., 2014). All the above mentioned studies provide evidence that the duration of starvation is decisive in determining which type and amount of energy storage will be synthesized, suggesting that the duration of starvation could be an important parameter to manipulate the accumulation of the two energyrich components, lipids and carbohydrates. For industrial applications, it would be ideal to achieve higher productivity and a higher relative content of reserves. However, optimizing both parameters is difficult because nitrogen limitation is required to trigger the accumulation of both starch and lipids (Ho et al., 2011).

Considering the types of reserves and their practical utilization for the production of bioethanol (from starch) or biodiesel (from lipids), green algae Parachlorella kessleri would be a promising microalgal strain to produce lipids for making biodiesel (Li et al., 2013), and 
Chlorella vulgaris (strain CCALA 924) would be appropriate as a feedstock for the production of bioethanol (Brányiková et al., 2011). Due to the high accumulation of starch, as well as lipids, under nitrogen starvation of Scenedesmus obliquus, this strain would be suitable both for the production of bioethanol and biodiesel (Breuer et al., 2014; Breuer et al., 2013; Ho et al., 2011; Ho et al., 2010; Vigeolas et al., 2012). Production can be further increased by raising starchless mutants that produce less starch and have improved lipid productivity because they direct most of their energy towards lipids while growth is not affected (Breuer et al., 2014; de Jaeger et al., 2014). This approach was originally used in Chlamydomonas reinhardtii (Li et al., 2010a; Li et al., 2010b; Wang et al., 2009; Work et al., 2010), where it led to at least a 10fold increase in storage lipids (Li et al., 2010a; Li et al., 2010b; Wang et al., 2009; Work et al., 2010). It was suggested that overproduction of neutral lipid by preventing starch synthesis is more effective than genetic engineering of the lipid biosynthetic pathway, which has only achieved limited success (Li et al., 2010a). Importantly, productivity can be further increased by nitrogen starvation in mixotrophic conditions (in the presence of $0.2 \%$ acetate) (Wang et al., 2009) and can be successfully used in other species, Chlorella sorokiniana, for example (Vigeolas et al., 2012).

In the starchless mutant Scenedesmus obliquus, both reserve lipids and starch accumulated markedly (45\% and 38\% DW, respectively). Under nitrogen starvation, lipid content reached $49.4 \%$ of DW without any decrease in production (de Jaeger et al., 2014).

In addition to the green algae (Chlorophyta), representatives of taxonomically different algal species were also found to be candidates for industrial utilization as carbohydrate or lipid producers. The alga Isochrysis sp. (Chromophyta, Haptophyceae) overproduced both carbohydrate and lipids under nitrogen starvation but in a different way. Carbohydrates increased and remained stable during starvation, while neutral lipids also accumulated but their content varied (Lacour et al., 2012). The lipid accumulation in the marine red alga 
Tichocarpus crinitus (Rhodophyta) increased markedly in algae grown at a high light intensity (Khotimchenko and Yakovleva, 2005).

\section{Approaches to increase accumulation of energy reserves}

\subsection{Applying specific inhibitors}

\subsubsection{Inhibition of nuclear DNA replication}

Specific inhibition of nuclear DNA synthesis by fluorodeoxyuridine (FdUrd) was used to study the regulation of cell cycle events and starch reserve synthesis in the chlorococcal alga Scenedesmus quadricauda (Zachleder, 1994; Zachleder, 1995). FdUrd inhibits the enzyme thymidylate synthase, which catalyzes the reductive methylation of $2^{\prime}$-deoxyuridylate to form deoxythymidylate (Bachmann et al., 1983; Cisneros et al., 1993; Follmann, 1983).

Inhibition of nuclear DNA (nuc-DNA) synthesis prevented nuclear division and cytokinesis (Zachleder et al., 1996), and in a synchronized culture, the daughter cells remained uninuclear with their initial nuc-DNA content and did not divide but continued to grow to a giant size and replicate chloroplast DNA for an interval corresponding to two or three unperturbed cell cycles and continuously accumulated starch.

\subsubsection{Inhibition of cytoplasmic proteosynthesis}

The antibiotic cycloheximide, a specific inhibitor of cytoplasmic proteosynthesis, prevented cultures of Scenedesmus quadricauda (Zachleder et al., 2002) and Chlorella vulgaris (Brányiková et al., 2011) from undergoing nuclear division and cell division. Starch, however, was intensively synthesized and in the case of Chlorella vulgaris, reached about 
$60 \%$ of DW (Fig. 2) (Brányiková et al., 2011), implying that starch synthesis in the chloroplast is independent of cytoplasmic protein synthesis and nuclear DNA replication.

On the one hand, application of specific inhibitors is advantageous for basic research because the mechanisms by which they affect cellular processes are known. On the other hand, their application in the industrial production of starch-enriched biomass is unacceptable because of their toxicity.

Therefore, for the prospective industrial scale-up of starch production, economically viable treatments that do not cause environmental contamination, but do enhance starch or lipid enriched biomass, must be chosen. Such treatments not only include the already widely used nutrient starvation discussed below but also may involve protocols with optimized combinations of light, carbon dioxide and temperature, or sub-lethal temperature as discussed above. Regardless of treatment or approaches, cellular processes and events consuming energy reserves must be minimized, while chloroplast processes such as photosynthesis and starch or lipid synthesis must be preserved. DNA replication, nuclear division, and cytokinesis belong to the main processes or events consuming most of the energy reserves (even under conditions favoring concomitant production of energy by photosynthesis). Indeed all treatments that in some way inhibit these processes led to the accumulation of reserves (mostly in the form of starch). Examples include the effects of FdUrd, cycloheximide, sublethal temperature or high light intensities described in sections above, the effects of benzopyrene (Abarzua et al., 1985), and high concentration of selenium compounds (Geoffroy et al., 2007; Vítová et al., 2011a).

\subsection{Nutrient starvation}


Macroelement (nitrogen, sulfur, or phosphorus) limitation is the most widely explored strategy and so far the most successful strategy for enhancing starch accumulation (Ball et al., 1990; Brányiková et al., 2011; Dragone et al., 2011) as well as for accumulating lipid reserves (Breuer et al., 2013; Li et al., 2013; Wu et al., 2013) and it is a viable and environmentally friendly option for the control of the cell cycle as a crucial condition for this enhancement.

\subsubsection{Nitrogen}

The intracellular partitioning of newly fixed carbon was studied using enzymatic and isotopic techniques in synchronized cells of Chlamydomonas reinhardtii. Starch and growth metabolism, that is, the use of carbon in biosynthesis, were found to be the major sinks for photosynthetically fixed carbon in the alga. Sucrose does not accumulate in significant quantities. The amount of carbon partitioned into either starch or growth varies during the 12-hour-light/12-hour-dark cell cycle. As we discussed above, starch is accumulated at the beginning and at the end of the light period, whereas a net breakdown is observed in the middle of the light period and in the dark. In contrast, non-synchronized cells accumulated starch all the time in the light, which suggested that carbon partitioning was controlled by the cell cycle. Accumulation of starch in the absence of nitrogen was observed in two consecutive cell cycles in synchronized cultures of Scenedesmus quadricauda (Ballin et al., 1988), where the absence of nitrate $\left(\mathrm{KNO}_{3}\right)$ prevented rRNA synthesis from the very beginning of the cell cycle and caused a decline to half of the initial content. Protein content slightly increased and then stopped. No DNA replication, and consequently, no nuclear or cellular division occurred. In contrast, starch accumulation proceeded at a rate similar to that in the control culture during the first half of the cycle but later slowed, attaining about half the amount per cell, characteristic of mother cells in the unlimited culture; no further synthesis occurred during 
prolonged incubation. Nevertheless, the relative starch content was very high (the ratio of starch to protein was more than four times higher than in normal cells) (Ballin et al., 1988). This report is, to our knowledge, the first one comprehensively studying the relationship between starch synthesis in nutrient limitation and cell cycle progression. Nutrient (sulfur) limitation was studied in synchronized algae Chlorella elipsoidea more than 50 years ago, but synthesis of energy reserves was not studied (Hase et al., 1961; Hase et al., 1960a; Hase et al., 1958; Hase et al., 1959). Starch synthesis during the cell cycle was also studied in synchronized Chlamydomonas (Duynstee and Schmidt, 1967; Klein, 1987) but not under nitrogen-limited conditions. In the first report, over-accumulation of energy reserves, both polysaccharides and lipids, under nitrogen starvation were described in two different species of the genus Chlorella. One of them, Chlorella sp. K, overproduced reserves in the form of polysaccharides (they called it the "carbohydrates strain"), while the second one, Chlorella pyrenoidosa, produced energy reserves in the form of lipids (the "lipid strain") (Semenenko et al., 1969; Semenenko et al., 1967; Zukova et al., 1969). Increased accumulation of starch (from $20 \%$ to $55 \%$ of DW) was also observed in a batch culture of Chlorella vulgaris grown photosynthetically under nitrogen limitation (Behrens et al., 1989). Later, the overproduction of starch under nitrogen starvation (10- to 50-fold increase in cellular starch content) was observed in Chlamydomonas reinhardtii (Ball, 1998; Ball et al., 1990). All these studies on the effect of nitrogen starvation on the accumulation of starch reserves were, at the time of publication, solely basic research without any vision with regard to biotechnological application. Today, however, this potential can be exploited.

The recent revival of research in directed accumulation of algal starch has been due to the assumption that algae could synthesize starch for the production of bioethanol for biofuels (for review, see (John et al., 2011)). The experimental approaches described for Scenedesmus quadricauda more than 25 years ago (Ballin et al., 1988; Šetlík et al., 1988; Zachleder et al., 
1988) were recently applied to obtain starch-enriched cultures of the industrially promising species Chlorella vulgaris (Brányiková et al., 2011). Some experimental approaches from this work were then successfully applied to the study of starch overproduction in the marine alga Tetraselmis subcordiformis (Yao et al., 2012). The authors proved that under nitrogen and sulfur starvation conditions, concomitantly with starch accumulation, changes in the ratio of amylose and amylopectin occurred. Nitrogen starvation was also applied in Scenedesmus obliquus to trigger the accumulation of both lipid and carbohydrate (Ho et al., 2011).

Nitrogen starvation for increased starch accumulation is not, however, used as frequently as the directed overproduction of lipids. The main reason is that the absence of nitrogen causes severe stress, leading to a nearly immediate cessation of biomass synthesis and, after a relatively short time, cell death (Ballin et al., 1988; Brányiková et al., 2011). Cell lysis due to nitrogen limitation (Eriksen et al., 2007) can lead to a decline in starch to half of its initial value (Brányiková et al., 2011), suggesting nitrogen starvation is not the optimal approach for the production of starch-enriched algal biomass for industrial applications. Moreover, the time after which total $\left(\mathrm{g} \mathrm{L}^{-1}\right)$ as well as relative (\% of DW) starch content began to decrease is short, particularly if the time needed to yield such a culture in a large-scale industrial photobioreactor is considered (Brányiková et al., 2011). Some authors tried to solve the problem by decreasing the concentration of nitrogen in mineral medium instead of a total absence of the element (Yao et al., 2012). By this approach, they succeeded in increasing the maximum biomass and starch concentrations, but maximum starch productivity $\left(\mathrm{g} \mathrm{L}^{-1} \mathrm{day}^{-1}\right)$ and relative content of starch (\% of DW) decreased. Therefore, for potential scaled-up applications, it would be important to find a compromise between maximum starch content $\left(\mathrm{g} \mathrm{L}^{-1}\right)$ and maximum starch relative content (\% of DW) (Yao et al., 2012); for example, it would be crucial to find the optimal harvesting time so that the biomass yield is achieved before a decline in starch content due to cell lysis. However, we believe that nitrogen 
starvation is by no means the optimal approach to induce starch overproduction, and sulfur starvation should be used in this case (see below).

While nitrogen starvation was not found to be the best way to achieve increased starch synthesis, it did effectively increase the accumulation of storage lipids. The first report on the effect of nitrogen starvation on Chlorella pyrenoidosa was published as early as 1949 (Spoehr and Milner, 1949) and showed that lipids increased from 5\% DW to 85\% of DW in nitrogen starved cells. A $75 \%$ decrease in nitrogen concentration in the medium, with respect to the optimal values for growth, increased the lipid fractions of $N$. oculata from $7.90 \%$ to $15.31 \%$ and of C. vulgaris from $5.90 \%$ to $16.41 \%$, respectively (Converti et al., 2009). Nitrogen deficiency is now the most efficient and frequently used approach to increase lipid content in various, often taxonomically different, algae, such as in Chlorophyta: Parachlorella kessleri (Li et al., 2013), Scenedesmus quadricauda (Zhao et al., 2012), Micractinium pusillum (Li et al., 2012), diatoms (Heterokontophyta, class Bacillariophyceae): Nitzschia closterium $f$. minutissima (Liu et al., 2012), Skeletonema marinoi (Bertozzini et al., 2013), Heterokontophyta, class Eustigmatophyceae: Nannochloropsis sp. (Pal et al., 2011; Rodolfi et al., 2009).

Of the nine species tested for lipid production under nitrogen starvation, four of them (Chlorella vulgaris, Chlorella zofingiensis, Neochloris oleoabundans, and Scenedesmus obliquus) attained a lipid content of more than $35 \%$ of their dry weight. In two strains $(S$. obliquus and C. zofingiensis), the duration of biomass productivity remained high for several days in the absence of nitrogen and showed the highest reserve lipid productivity (322 and $243 \mathrm{mg}^{-1}$ day $^{-1}$ (Breuer et al., 2012).

For biofuel production from algae, neutral lipids (triacylglycerols) produced under nitrogen deficiency are the most convenient. Generally, microalgae used for lipid production can generally be divided into two categories: (1) high lipid content but low cell growth; (2) 
high cell growth but low lipid content. Much of the early research on oil production from photosynthetic microalgae focused on the search for species with a high oil content. However, the species with the highest oil content grew most slowly, resulting in low rates of oil production (Lv et al., 2010). The main weakness of the nitrogen starvation treatment is that growth rate is greatly decreased (Bertozzini et al., 2013; Hsieh and Wu, 2009; Lv et al., 2010; Pruvost et al., 2011; Rodolfi et al., 2009).

To overcome this bottleneck, a two-step procedure for lipid production was developed. In the first step, optimal growth conditions for production of biomass are maintained (complete mineral medium, light, temperature, and $\mathrm{CO}_{2}$ ). Then the culture conditions are changed to introduce sufficient stress to induce over-accumulation of lipids. This approach was tested in two strains of Chlorella sp. and one strain of Scenedesmus, using different sources of nitrogen $\left(\mathrm{NaNO}_{3}, \mathrm{KNO}_{3}\right.$ and urea) for growth and their limitation for lipid production (Ratha et al., 2013). For Chlorella vulgaris, nutrient rich conditions, followed by nitrogen starvation, induced overproduction of lipids to 53\% of DW (Mujtaba et al., 2012), which was also similar to the effect of the procedure on increased lipid production in Neochloris oleoabundans (Klok et al., 2013) and in Parachlorella kessleri growing in complete mineral medium of different concentrations followed by starvation for nitrogen, phosphorus or sulfur, or a combination of all nutrients in depleted diluted media ( $\mathrm{Li}$ et al., 2013). The cost of the procedure could be further decreased by omitting $\mathrm{CO}_{2}$ supply in the depletion phase when biomass increase ceased (Li et al., 2013).

In spite of the overwhelming body of evidence on the induction of over-accumulation of storage lipids by nitrogen limitation, there are several reports showing that lipids can accumulate just after repletion of a high concentration of nitrogen but not under nitrogen starvation conditions. This was the case in the marine oleaginous microalgae Isochrysis zhangjiangensis (Chrysophyta), which accumulated lipids to 53\% of DW at a high 
concentration of nitrate $\left(9 \mathrm{~g} \mathrm{~L}^{-1}\right)$; such a strain, grown in nitrogen rich wastewaters, could be ideal for the production of lipids for biodiesel (Feng et al., 2011). Overproduction of store lipids without nutrient limitation was also found in two mutated strains of Parachlorella kessleri produced by heavy-ion mutagenesis (Ota et al., 2013). A mutant of Desmodesmus sp. produced by the same method accumulated much more lipid than wild type, but for lipid accumulation, nitrogen limitation was required (Hu et al., 2013).

\subsubsection{Phosphorus}

Phosphorus starvation can induce starch or lipid accumulation in a fashion similar to limitations of other macroelements, depending on the specific species or strain, and in some cases, on the length of the starvation period. In oleaginous algae, only lipids accumulate. In Nannochloropsis under phosphorus starvation conditions, lipids increased to 50\% DW (Rodolfi et al., 2009).

A study of the effect of phosphorus deficiency on cell cycle progression in a synchronized culture of Chlamydomonas reinhardtii showed that during the first cell cycle RNA synthesis was already inhibited, and protein synthesis slowed down, leading to a reduced number of DNA replication rounds, nuclear divisions, and released daughter cells (Lien and Knutsen, 1973). Similar effects of phosphorus deficiency were observed during the first cell cycle of synchronized Scenedesmus quadricauda. During the second cell cycle, practically all macromolecular syntheses (DNA, RNA, protein), except starch, ceased and no nuclear or cellular division occurred (Zachleder et al., 1988). Phosphorus limitation in Chlorella vulgaris slowed dry weight increases and stopped cell division completely after $12 \mathrm{~h}$ of growth. The relative content of starch in phosphorus-starved cells (in \% of DW) was lower than in sulfur-starved Chlorella vulgaris cells (Brányiková et al., 2011), similar to the marine alga Tetraselmis subcordiformis (Yao et al., 2013; Yao et al., 2012). 
Several species (Scenedesmus sp., Chlorella ellipsoidea, Chlorella vulgaris, Chlorella sorokiniana, Chlorella pyrenoidosa, Dunaliella primolecta, and Haematococcus pluvialis) accumulated lipids instead of starch under conditions of phosphorus starvation (Wu et al., 2013). Scenedesmus sp. was shown to be particularly suitable for scaled-up production of biofuels because the highest potential biomass yield of $6100 \mathrm{~kg}$ biomass per $\mathrm{kg} \mathrm{P}$ and lipid accumulation to about $30 \%$ of biomass DW were obtained with the lowest phosphorus content (Wu et al., 2013). Elimination of phosphorus also induced lipid accumulation in Parachlorella kessleri, and the culture accumulated lipid to nearly the same extent as under nitrogen limitation (Li et al., 2013).

\subsubsection{Sulfur}

Comparison of six oleaginous algal species (Thalassiosira pseudonana, Odontella aurita, Nannochloropsis oculata, Isochrysis galbana, Chromulina ochromonoides, and Dunaliella tertiolecta) grown at $10{ }^{\circ} \mathrm{C}$ and $20{ }^{\circ} \mathrm{C}$ in complete and sulfur-depleted mineral media showed that growth rate and fatty acid content were negatively correlated, suggesting that nutrient limitation was the most important factor affecting lipid metabolism (Breuer et al., 2013). A specific role for sulfur in cell reproductive processes has been proposed by several authors, who found that cellular division in Chlorella ellipsoidea is blocked in the absence of sulfur (Hase et al., 1960a; Hase et al., 1960b; Hase et al., 1958; Hase et al., 1960c; Hase et al., 1959; Tamiya, 1964). In spite of the fact that these authors did not follow starch or lipid synthesis in their experiment, it was later repeatedly proven that it was particularly the inhibition of DNA replication-division events that caused overproduction of energy reserves under nutrient limitation. Specific analysis of the effect of sulfur absence on the time course of macromolecular syntheses, and nuclear and cellular division events, for two cell cycles in synchronized cultures of Scenedesmus quadricauda showed that macromolecular syntheses 
(RNA, protein) were arrested during the second cell cycle concomitantly with blocked nuclear and cellular division (Šetlík et al., 1988). However, photosynthesis continued and starch accumulated as it did in cells grown in complete medium. Because normal starch synthesis was accompanied by very poor cell growth, the ratio of starch to protein (or dry matter) was much higher than in the control culture, as was later confirmed in Chlorella vulgaris (Brányiková et al., 2011). Due to the presence of reserves, starved cells that were refed with sulfur commenced RNA, protein, and DNA synthesis immediately, and were able to pass the entire cell cycle in the dark while dividing into eight daughter cells (Šetlík et al., 1988). This not only suggests the importance of sulfur for cell cycle progression but also indicates yet another way that starch reserves are important for cell cycle events as well as for the entire metabolism.

Of all the nutrient (nitrogen, phosphorus) limiting treatments, sulfur starvation yields a maximum relative starch content up to $60 \%$ of DW. Moreover, the high starch content was maintained for a long period (Brányiková et al., 2011; Šetlík et al., 1988), which suggests sulfur limitation was the most effective method of enhancing starch productivity and content. A similar enhancing effect of sulfur deprivation on starch synthesis was described in Chlamydomonas reinhardtii, where a nearly 10-fold increase in cellular starch content occurred (Zhang et al., 2002) and in Dunaliella salina where a 10-fold increase in starch-toprotein ratios was induced under sulfur-deprived conditions (Cao et al., 2001). Regarding differences between sulfur and nitrogen or phosphorus starvation effects, it is apparent that the amount of sulfur required for cell growth and reproduction is not so high, and its limitation does not have such severe consequences as in the case of phosphorus and particularly nitrogen limitation. This is also supported by the fact that under sulfur deprivation, starch content did not decrease for at least 15 hours (Brányiková et al., 2011), which is crucial for scaled-up culturing for industrial production of starch-enriched algal 
biomass, providing sufficient time for high yields of algae in large bioreactors. Large-scale cultivation usually takes place in outdoor solar photobioreactors under an illumination regime of alternating light (day) and dark (night) periods. In Chlorella vulgaris, with cultures grown in complete mineral medium under alternating light/dark intervals, decreased biomass concentration during the dark period was caused mainly by extensive degradation of starch (the net production of starch during light was degraded in the dark). The sulfur-starved cultures grew slower than control cultures, but the biomass concentration did not decrease during the dark interval. Sulfur limitation stopped cell division, preventing bulk starch degradation during the dark interval. Consequently, in sulfur-starved cultures, both absolute and relative contents of starch increased markedly (from about 0.02 to $0.7 \mathrm{~g} \mathrm{~L}^{-1}$ and from $7 \%$ to $60 \%$ of DW respectively) (Brányiková et al., 2011).

The same approach of sulfur starvation, when applied to algal strains suitable for overproduction of lipids, was found to be less effective when compared to nitrogen starvation conditions (Brányiková et al., 2011; Li et al., 2013); this explains why so few reports deal with the production of lipids under sulfur starvation. However, the clear effect of sulfur limitation on inducing starch and lipid synthesis can be used to study mutual relationships in those algal strains and species that can accumulate both starch and lipids under starvation conditions (Mizuno et al., 2013). Such studies on different algal species confirm the findings regarding nitrogen limitation, for example, the transient accumulation of starch followed by a steady increase in lipid storage in the form of lipid droplets (Mizuno et al., 2013; Takeshita et al., 2014).

Similar to nitrogen starvation, sulfur deficiency also altered the fatty acid composition in Chlorella lobophora, Parachlorella kessleri (Takeshita et al., 2014), and Chlorella ellipsoidea (Otsuka and Morimura, 1966). 


\subsubsection{Nutrient depletion}

Growth of algal cultures in scaled-up bioreactors requires relatively expensive mineral medium containing soluble salts of several macro- and microelements. It can be assumed that removing all elements, rather than individual ones, could induce the same or possibly higher hyper-accumulation of lipids with additional beneficial savings. Indeed, over-accumulation of lipids in Parachlorella kessleri cultures grown in 5- and 10-fold diluted medium led to a higher accumulation of lipids when compared with nitrogen starvation, as well as with less efficient sulfur or phosphorus starvation (Fernandes et al., 2013; Li et al., 2013). The same effect was confirmed for 10 different strains of Chlorella sorokiniana, Chlorella vulgaris, and Parachlorella kessleri (Přibyl et al., 2012) as well as in large-scale, outdoor, open, solar photobioreactors used for commercial purposes (Fernandes et al., 2013; Li et al., 2013). Thus, depletion of elements from mineral medium by growth of algal biomass seems to be the most effective way for achieving maximum lipid over-accumulation and for cost savings. However, it should be kept in mind that an important condition for efficient overproduction of storage lipids by nutrient depletion is sufficient light energy (mean light intensity) at the time of depletion. Therefore, it is necessary to use the two-step process described above: grow cell cultures in an appropriately concentrated nutrient medium to attain a sufficiently low biomass concentration under sufficiently high mean light intensity, as required for successful lipid production, followed by the period of depletion.

\subsection{Lipid bodies}

\subsubsection{Description, localization, appearance, visualization}

While starch reserves in green algae are located exclusively in chloroplasts in the form of starch grains, the reserve neutral lipids (triacylglycerols) are stored mostly in the cytoplasm in 
the form of specialized structures called lipid or oil bodies, or lipid droplets, and only some of them are located in chloroplasts. Lipid bodies are round organelles with a basic function of energy and carbon storage. The neutral lipids, being the main component of lipid bodies, are surrounded by a monolayer of phospholipids and a number of proteins. These proteins carry out distinct functions, making lipid bodies highly active organelles that not only govern the storage and turnover of lipids but also regulate the synthesis and transport of lipids, protein storage and degradation, and interactions with other organelles (Moellering and Benning, 2010; Shibata et al., 2009; Shibata et al., 2010; Yang et al., 2012).

The lipid bodies were found practically in all algae studied up to now, in a wide range of taxonomic groups. For visualization of lipid bodies (even within live algal cells) and the quantification of the content of lipids in them, the fluorescent stain Nile Red (9-diethylamino5H-benzo ( $\alpha$ )phenoxazine-5-one) has been used for more than 20 years (Cooksey et al., 1987; de la Jara et al., 2003; Chen et al., 2009). Lipid bodies of various sizes were described after Nile Red staining of Chlorella vulgaris (Přibyl et al., 2012) and Chlamydomonas reinhardtii (Siaut et al., 2011; Wang et al., 2009; Work et al., 2010).

More recently (Cooper et al., 2010), the fluorescent stain Bodipy 505/515 (4,4-difluoro1,3,5,7-tetramethyl-4-bora-3a,4adiaza-s-indacene), has begun to be used for visualization of algal store lipids and their quantification. The effective staining of lipid bodies with Bodipy is possible even in those algae with thick cell walls and, more specifically, bound lipid bodies. Bodipy-stained lipid bodies were visualized in taxonomically remote algal species, such as dinoflagellate Prorocentrum sp., Ophiocytium maius (Xanthophyceae) with an elongated cylindroid cell, Chrysochromulina sp. (Haptophyceae) with naked cells, and Mallomonas splendens (Synurophyceae), an alga covered with silica scales (Cooper et al., 2010). Lipid bodies of various sizes and numbers were described in Chlorella vulgaris (Přibyl et al., 2013), Chlamydomonas reinhardtii(Siaut et al., 2011; Wang et al., 2009; Work et al., 2010), 
Parachlorella kessleri (Li et al., 2013), and in the starchless mutant strain, Chlorella pyrenoidosa STL-PI, cultivated under nitrogen limitation conditions (Ramazanov and Ramazanov, 2006). Detailed electron microscopic studies of lipid body ultrastructure were described in Chlorella (Přibyl et al., 2013) and Chlamydomonas reinhardtii (Goodson et al., 2011).

Detailed analyses of the accumulation of lipid bodies in chloroplasts and the cytoplasm of both wild type and the starchless mutant, sta6 Chlamydomonas reinhardtii, revealed that production of lipid bodies under nitrogen starvation was markedly increased in mixotrophic conditions in the presence of exogenous acetate. The lipid bodies filled nearly the entire volume of the cell, and the cells floated, failing to settle with centrifugation. Biochemical pathways and genes involved in the overproduction of lipids were also described (Goodenough et al., 2014; Goodson et al., 2011). A similar increase in the size of lipid bodies and their fusion into one huge lipid body, occupying most of the cell volume, was also observed in Chlorella and Parachlorella, under nutrient limitation (Přibyl et al., 2012).

\subsubsection{Function of lipid bodies}

The most important function of lipid bodies is to serve as a source of energy and carbon in case the supply from photosynthesis is not sufficient (e.g., low light intensity or darkness), or during recovery in replenished mineral medium following nutrient starvation (Fernandes et al., 2013). After replenishment of the nutrient medium, the large lipid bodies were fragmented into smaller ones, and the lipid level decreased rapidly to nearly zero; similar to the starch reserves; such mobilization of the cellular lipid store occurred even in darkness (Fernandes et al., 2013; Přibyl et al., 2013), suggesting shared functions between both types of energy reserves. 
However, the role of lipid bodies in algae is not limited to their storage function but plays an important role in adaptation to environmental conditions: 1) lipid bodies supply long-chain fatty acids necessary for rearrangement of the photosynthetic apparatus and cellular membranes; 2) production of lipids and their storage in lipid bodies serve as energy sinks, consuming photo-assimilates produced under stress when their production could lead to photo-oxidative damage; 3) lipid bodies can serve as a depot for lipophilic carotenoids, creating an optical screen, which protects the cell grown at high light intensities against photo-damage. Accumulation of carotenoids, particularly under stress conditions, was observed in Haematococcus pluvialis (Chlorophyta, Volvocales) (Peled et al., 2012; Wayama et al., 2013), Dunaliella bardawil (Rabbani et al., 1998), D. salina (Chlorophyta, Volvocales) (Lamers et al., 2012), Parietochloris incisa (Chlorophyta, Trebouxiophyceae) (Solovchenko and Merzlyak, 2008), and two species of Trentepohlia (Chlorophyta, Trentepohliales) (Mukherjee et al., 2010), (for more detailed review, see (Solovchenko, 2012).

\section{Conclusion}

Microalgae produce two types of carbon-based energy reserves: polyglucans and lipids. The type of polyglucan is group specific, with starch being the staple polyglucan of green algae (Chlorophyta), localized to the chloroplast in the form of starch grains. Lipid composition is, in contrast to polyglucans, variable. Their molecules (triacylglycerols) consist of glycerol esterified with three fatty acids, which can be the same or different, with different lengths and levels of saturation. Their composition varies, depending not only on the species of algae but also the cultivation conditions. Lipids accumulate mainly in the cytoplasm in the form of lipid bodies. The lipid bodies function not only as an energy reserve storage but also as a source of long-chain fatty acids for the photosynthetic apparatus and cellular membranes, as well as storage of lipophilic carotenoids that serve as efficient photo-damage protectors under high 
light intensity. Both energy compounds serve primarily as buffers in an extremely variable external energy (e.g. light) and carbon (carbon dioxide) supply. They are used to support both cell growth and division, and also serve as an energy sink, consuming photo-assimilates under strong light or when energy consumption by growth and cell division is blocked by nutrient starvation or other factors.

Most green algae (Chlorophyta) can produce both starch and lipids but overproduction of one or another type is distinct in different species or strains and can be regulated by growth conditions. In most of the "starch strains", starch production is inducible. However, lipid production is inducible only in some strains ("lipid strains"). By mutating starch metabolism, starch species like Chlamydomonas and others can be changed into lipid ones; they will be unable to produce starch anymore and will produce lipids instead. In all species, regardless of whether they are the starch or lipid type, starch is intensively accumulated shortly after the beginning of nutrient starvation or other stress treatments, whereas storage lipid accumulation in lipid strains starts within hours or days later, accompanied by degradation of previously accumulated starch. Clearly, the selection of an appropriate algal strain for starch or lipid overproduction is a key step in the selection of appropriate algal species, particularly in scaled-up photobioreactors for industrial purposes.

For any over-accumulation, it should be kept in mind that the energy compound will be stored only if the content of energy reserves exceeds that required for growth, for example, the net content will increase. To attain the maximal accumulation of reserves, three basic conditions require optimization: 1) light intensity; 2) temperature; and 3) carbon dioxide concentration. This is particularly challenging for large-scale outdoor cultivation, where fulfilling each of these conditions brings additional costs to the production of biomass. The ideal location for large-scale cultivation will be in close vicinity to a source of cheap carbon dioxide, such as flue gas, and in areas with stable, high light intensity and temperatures that 
only change mildly with the season. Moreover, a source of cheap fertilizers, ideally, mineral rich wastewaters, as well as water for cooling, is also required. The number of locations fulfilling all criteria is very limited; therefore, the choice of a particular location is a trade-off offering the most feasible situation economically.

Even under optimized conditions, when the maximum production of energy reserves is reached, the majority of these reserves will be spent during darkness to support cell survival and especially to sustain cell cycle processes, such as DNA replication, nuclear and cellular division, which are the major energy consumers. Thus, if the cell cycle remains undisturbed, the majority of any accumulated energy reserves will, under natural conditions, be spent during the night. Clearly, to maximize energy over-accumulation in biotechnologically relevant outdoor conditions, two conditions must be fulfilled: 1) optimal growth conditions; 2) limitation of energy-requiring cell cycle events.

Blocking the cell cycle can be achieved under laboratory conditions by the application of specific inhibitors of DNA replication or proteosynthesis. The affected cells grow and produce starch normally. Because the starch is not spent by blocked cell cycle processes, it will over-accumulate. Such treatments are advantageous for basic research because the mechanisms by which they affect cellular processes can be studied, but they are not practical for large-scale cultivation because of cost and toxicity of the inhibitors as well as that of subsequent biomass.

Cell cycle events, particularly DNA replication and nuclear and cellular division, can be easily blocked by macroelement (nitrogen, sulfur, or phosphorus) limitation. This is the most widely explored industrial strategy because it is both economically viable and an environmentally friendly strategy for enhancing starch as well as lipid accumulation. The nutrient limitation clearly cuts the cost of adding the limiting macroelement. A better treatment, compared with particular macroelement limitation, is achieved by using an 
appropriately diluted mineral medium, leading to the depletion of all elements by growing algae. Such a treatment is not only simple, particularly in large volumes of algal suspension in mass cultivation, but also the most effective way to achieve maximum lipid over-accumulation and save costs.

The main bottleneck of the nutrient limitation approach is that it not only blocks the processes of the cell cycle but also limits growth, particularly protein synthesis, if prolonged as long as is required for lipid accumulation. To overcome this, a two-step procedure for lipid production can be exploited. In the first step, optimal growth conditions for biomass production are maintained (complete mineral medium, optimal light, temperature, and $\mathrm{CO}_{2}$ ). Next, the algal cultures are exposed to nutrient stress to induce over-accumulation of lipids or starch. In large-scale outdoor open solar photobioreactors, the first step includes the choice of an appropriate concentration of mineral medium enabling the cell culture to grow to the desirable biomass concentration at which the nutrients in the medium are depleted. The second step, the over-accumulation of energy reserves, naturally follows once the medium is depleted, thereby saving costs for fertilizer and $\mathrm{CO}_{2}$.

Microalgae have been praised as potential industrial energy compound producers. Here, we explain the relationship between energy reserve accumulation and cell cycle progression, and that basic research predictions of algal behavior can be used in biotechnological processes, and thus improve them without any further trial and error. We strongly believe this approach is indispensable to speed up the development of algal-based biotechnology. Thus, we argue that not only product-driven research but also basic research will be of benefit to the final goal of sustainable production.

\section{Acknowledgements}


The work was supported by the National Programme of Sustainability I, ID: LO1416, by grant of Grant Agency of the Czech Republic no. 15-09231S (V.Z, K.B., and M.V.) and by JST, CREST (S.K,)

\section{References}

Abarzua AS, Wittenburg E, Sulek J, Zachleder V. Die Wirkung von 3,4-Benzpyren auf die Ultrastruktur der Grünalge Scenedesmus quadricauda in Synchronkultur. Arch Protistenk $1985 ; 130: 143-55$.

Adams C, Bugbee B. Enhancing lipid production of the marine diatom Chaetoceros gracilis: synergistic interactions of sodium chloride and silicon. J Appl Phycol 2014;26:1351-7.

Allen AE, Dupont CL, Obornik M, Horak A, Nunes-Nesi A, McCrow JP et al. Evolution and metabolic significance of the urea cycle in photosynthetic diatoms. Nature 2011;473:2037.

Bachmann B, Hofmann R, Follmann H. Tight coordination of ribonucleotide reduction and thymidilate synthesis in synchronous algae. FEBS Lett 1983;152:247-50.

Ball SG. Regulation of starch biosynthesis. In: Rochaix J-D, Goldschmidt-Clermont M, Merchant S, editors. The molecular biology of chloroplasts and mitochondria in Chlamydomonas. The Netherlands: Kluwer Academic Publishers; 1998, p. 549-67.

Ball SG, Dirick L, Decq A, Martiat JC, Matagne RF. Physiology of starch storage in the monocellular alga Chlamydomonas reinhardtii. Science 1990;66:1-9.

Ballin G, Doucha J, Zachleder V, Šetlík I. Macromolecular syntheses and the course of cell cycle events in the chlorococcal alga Scenedesmus quadricauda under nutrient starvation: Effect of nitrogen starvation. Biol Plantarum 1988;30:81-91. 
Behrens PW, Bingham SE, Hoeksema SD, Cohoon DL, Cox JC. Studies on the incorporation of $\mathrm{CO}_{2}$ into starch by Chlorella vulgaris. J Appl Phycol 1989;1:123-30.

Berg JM, Tymoczko JL, Stryer L. Triacylglycerols are highly concentrated energy stress. New York: W H Freeman; 2002.

Berková E, Doucha J, Kubín Š, Zachleder V, Šetlík I. Variation in photosynthetic characteristics of Scenedesmus quadricauda during the cell cycle. Proc 2nd Intern Congr Photosynth Res, The Hague, Dr. W. Junk N.V. Publishers; 1972, p.2619-32.

Bertozzini E, Galluzzi L, Ricci F, Penna A, Magnani M. Neutral lipid content and biomass production in Skeletonema marinoi Bacillariophyceae) culture in response to nitrate limitation. Appl Biochem Biotechnol 2013;170:1624-36.

Bišová K, Zachleder V. Cell-cycle regulation in green algae dividing by multiple fission. J Exp Bot 2014;65:2585-602.

Borowitzka MA, Moheimani NR. Algae for Biofuels and Energy. Dordrecht: Springer Netherlands; 2013.

Brányiková I, Maršálková B, Doucha J, Brányik T, Bišová K, Zachleder V et al. Microalgaenovel highly efficient starch producers. Biotechnol Bioeng 2011;108:766-76.

Brennan L, Owende P. Biofuels from microalgae-A review of technologies for production, processing, and extractions of biofuels and co-products. Renew Sustain Energy Rev 2010;14:557-77.

Breuer G, de Jaeger L, Artus VPG, Martens DE, Springer J, Draaisma RB et al. Superior triacylglycerol (TAG) accumulation in starchless mutants of Scenedesmus obliquus: (II) evaluation of TAG yield and productivity in controlled photobioreactors. Biotechnol Biofuels 2014;7:70. 
Breuer G, Lamers PP, Martens DE, Draaisma RB, Wijff RH. Effect of light intensity, pH, and temperature on triacylglycerol (TAG) accumulation induced by nitrogen starvation in Scenedesmus obliquus. Bioresour Technol 2013;143:1-9.

Breuer G, Lamers PP, Martens DE, Draaisma RB, Wijffels RH. The impact of nitrogen starvation on the dynamics of triacylglycerol accumulation in nine microalgae strains. Bioresour Technol 2012;124:217-26.

Cao H, Zhang L, Melis A. Bioenergetic and metabolic processes for the survival of sulfurdeprived Dunaliella salina (Chlorophyta). J Appl Phycol 2001;13:25-34.

Cisneros RJ, Zapf JW, Dunlap RB. Studies of 5-fluorodeoxyuridine 5'-monophosphate binding to carboxypeptidase A-inactivated thymidylate synthase from Lactobacillus casei. J Biol Chem 1993;268:10102-8.

Cole DG, Diener DR, Himelblau AL, Beech PL, Fuster JC, Rosenbaum JL. Chlamydomonas kinesin-II-dependent intraflagellar transport (IFT): IFT particles contain proteins required for ciliary assembly in Caenorhabditis elegans sensory neurons. J Cell Biol 1998;141:993-1008.

Converti A, Casazza AA, Ortiz EY, Perego P, Del Borghi M. Effect of temperature and nitrogen concentration on the growth and lipid content of Nannochloropsis oculata and Chlorella vulgaris for biodiesel production. Chem Eng Process 2009;48:1146-51.

Cooksey KE, Guckert JB, Williams S, Callis PR. Fluorometric determination of the neutral lipid content of microalgal cells using Nile Red. J Microbiol Methods 1987;6:333-45.

Cooper MS, Hardin WR, Petersen TW, Cattolico RA. Visualizing "green oil" in live algal cells. J Biosci Bioeng 2010;109:198-201.

Curnutt SG, Schmidt RR. Possible mechanisms controlling the intracellular level of inorganic polyphosphate during synchronous growth of Chlorella pyrenoidosa. II. ATP/ADP ratio. Biochim Biophys Acta 1964;86:201-3. 
Červený J, Sinetova MA, Valledor L, Sherman LA, Nedbal L. Ultradian metabolic rhythm in the diazotrophic cyanobacterium Cyanothece sp. ATCC 51142. P Natl Acad Sci USA 2013;110:13210-5.

de Jaeger L, Verbeek R, Draaisma R, Martens D, Springer J, Eggink G et al. Superior triacylglycerol (TAG) accumulation in starchless mutants of Scenedesmus obliquus: (I) mutant generation and characterization. Biotechnol Biofuels 2014;7:69.

de la Jara A, Mendoza H, Martel A, Molina C, Nordstron L, de la Rosa V et al. Flow cytometric determination of lipid content in a marine dinoflagellate, Crypthecodinium cohnii. J Appl Phycol 2003;15:433-8.

de Winter L, Klok AJ, Cuaresma FM, Barbosa MJ, Wijffels RH. The synchronized cell cycle of Neochloris oleoabundans and its influence on biomass composition under constant light conditions. Algal Res 2013;2:313-20.

Doucha J, Lívanský K. Productivity, $\mathrm{CO}_{2} / \mathrm{O}_{2}$ exchange and hydraulics in outdoor open high density microalgal (Chlorella sp.) photobioreactors operated in a Middle and Southern European climate. J Appl Phycol 2006;18:811-26.

Doucha J, Straka F, Livansky K. Utilization of flue gas for cultivation of microalgae (Chlorella sp.) in an outdoor open thin-layer photobioreactor. J Appl Phycol 2005;17:40312.

Douskova I, Doucha J, Livansky K, Machat J, Novak P, Umysova D et al. Simultaneous flue gas bioremediation and reduction of microalgal biomass production costs. Appl Microbiol Biotechnol 2009;82:179-85.

Doušková I, Kaštánek F, Maléterová Y, Kaštánek P, Doucha J, Zachleder V. Utilization of distillery stillage for energy generation and concurrent production of valuable microalgal biomass in the sequence: biogas-cogeneration-microalgae-products. Energy Convers Mngm 2010;51:606-11. 
Dragone G, Fernandes BD, Abreu AP, Vicente AA, Teixeira JA. Nutrient limitation as a strategy for increasing starch accumulation in microalgae. Appl Energy 2011;88 3331-5.

Dron A, Rabouille S, Claquin P, Le Roy B, Talec A, Sciandra A. Light-dark (12:12) cycle of carbon and nitrogen metabolism in Crocosphaera watsonii WH8501: relation to the cell cycle. Environ Microbiol 2012;14:967-81.

Dron A, Rabouille S, Claquin P, Talec A, Raimbault V, Sciandra A. Photoperiod length paces the temporal orchestration of cell cycle and carbon-nitrogen metabolism in Crocosphaera watsonii. Environ Microbiol 2013;15:3292-304.

Duynstee EE, Schmidt RR. Total starch and amylose levels during synchronous growth of Chlorella pyrenoidosa. Arch Biochem Biophys 1967;119:382-6.

Eriksen NT, Riisgard FK, Gunther WS, J. LIJ. On-line estimation of $\mathrm{O}(2)$ production, $\mathrm{CO}(2)$ uptake, and growth kinetics of microalgal cultures in a gas-tight photobioreactor. J Appl Phycol 2007;19:161-74.

Feng DN, Chen ZA, Xue S, Zhang W. Increased lipid production of the marine oleaginous microalgae Isochrysis zhangjiangensis (Chrysophyta) by nitrogen supplement. Bioresour Technol 2011;102:6710-6.

Fernandes B, Teixeira J, Dragone G, Vicente AA, Kawano S, Bišová K et al. Relationship between starch and lipid accumulation induced by nutrient depletion and replenishment in the microalga Parachlorella kessleri. Bioresour Technol 2013;144:268-74.

Follmann H. Deoxyribonucleotide biosynthesis: A critical process for life. In: Pullman B, Jortner J, editors. Nucleic acids: The vectors of life. D. Reidel Publishing Company; 1983, p. 547-57.

Gardner RD, Lohman E, Gerlach R, Cooksey KE, Peyton BM. Comparison of $\mathrm{CO}_{2}$ and bicarbonate as inorganic carbon sources for triacylglycerol and starch accumulation in Chlamydomonas reinhardtii. Biotechnol Bioeng 2013;10:87-96. 
Geoffroy L, Gilbin R, Simon O, Floriani M, Adam C, Pradines C et al. Effect of selenate on growth and photosynthesis of Chlamydomonas reinhardtii. Aquat Toxicol 2007;83:14958.

Gigova L, Ivanova N, Gacheva G, Andreeva R, Furnadzhieva S. Response of Trachydiscus minutus (Xanthophyceae) to temperature and light. J Phycol 2012;48:85-93.

Goodenough U, Blaby I, Casero D, Gallaher SD, Goodson C, Johnson S et al. The path to triacylglyceride obesity in the sta6 strain of Chlamydomonas reinhardtii. Eukar Cell 2014;13:591-613.

Goodson C, Roth R, Wang ZT, Goodenough U. Structural correlates of cytoplasmic and chloroplast lipid body synthesis in Chlamydomonas reinhardtii and stimulation of lipid body production with acetate boost. Eukar Cell 2011;10:1592-606.

Harder R, von Witsch H. Bericht über Versuche zur Fettsynthese mittels autotropher Microorganismen. Forschungsdienst Sonderheft 1942a;16:270-5.

Harder R, von Witsch H. Die Massenkultur von Diatomeen. Ber. Ber Deutsch Bot Ges 1942b;60:146-52.

Harwood JL, Guschina IA. The versatility of algae and their lipid metabolism. Biochimie 2009;91: 679-84.

Hase E, Mihara S, Otsuka H, Tamiya H. Role of sulfur in the cell division of Chlorella, with special reference to the sulfur compounds appearing during the process of cell division II. Plant Cell Physiol 1961;2:9-24.

Hase E, Mihara S, Tamiya H. Role of sulfur in the cell division of Chlorella, with special reference to the sulfur compounds appearing during the process of cell division I. Plant Cell Physiol 1960a;1:131-42.

Hase E, Mihara S, Tamiya H. Sulphur-containing deoxypentose polynucleotides obtained from Chlorella. Biochim Biophys Acta 1960b;39:381-2. 
Hase E, Morimura Y, Mihara S, Tamiya H. The role of sulfur in the cell division of Chlorella. Arch Mikrobiol 1958;32:87-95.

Hase E, Morimura Y, Tamiya H. A short remark on the role of sulfur in the cell division of Chlorella. J Gen Appl Microbiol, 1960c;6:68-9.

Hase E, Otsuka H, Mihara S, Tamiya H. Role of sulfur in the cell division of Chlorella studied by technique of synchronous culture. Biochim Biophys Acta 1959;35:180-9.

Herrmann EC, Schmidt RR. Synthesis of phosphorus-containing macromolecules during synchronous growth of Chlorella pyrenoidosa. Biochim Biophys Acta 1965;95:63-75.

Hildebrand M, Abbriano RM, Polle JEW, Traller JC, Trentacoste EM, Smith SR et al. Metabolic and cellular organization in evolutionarily diverse microalgae as related to biofuels production. Curr Opin Chem Biol 2013;17:506-14.

Hildebrand M, Davis AK, Smith SR, Traller JC, Abbriano R. The place of diatoms in the biofuels industry. Biofuels 2012;3:221-40.

Hirokawa T, Hata M, Takeda H. Correlation between the starch level and the rate of starch synthesis during the development cycle of Chlorella ellipsoidea. Plant Cell Physiol 1982;23:813-20.

Ho S-H, Chen C-Y, Chang J-S. Effect of light intensity and nitrogen starvation on $\mathrm{CO}_{2}$ fixation and lipid/carbohydrate production of an indigenous microalga Scenedesmus obliquus CNW-N. Bioresour Technol 2011;113:244-52.

Ho S-H, Chen W-M, Chang J-S. Scenedesmus obliquus CNW-N as a potential candidate for $\mathrm{CO}_{2}$ mitigation and biodiesel production. Bioresour Technol 2010;101:8725-30.

Hsieh C-H, Wu W-T. Cultivation of microalgae for oil production with a cultivation strategy of urea limitation. Bioresour Technol 2009;100:3921-6. 
Hu G, Fan Y, Zhang L, Yuan C, Wang J, Li W et al. Enhanced lipid productivity and photosynthesis efficiency in a Desmodesmus sp. mutant induced by heavy carbon ions. PLoS One 2013;8:1-8.

Hu Q, Sommerfeld M, Jarvis E, Ghirardi M, Posewitz M, Seibert M et al. Microalgal triacylglycerols as feedstocks for biofuel production: perspectives and advances. Plant $\mathbf{J}$ 2008;54:621-39.

Chen W, Zhang CW, Song LR, Sommerfeld M, Hu Q. A high throughput Nile red method for quantitative measurement of neutral lipids in microalgae. J Microbiol Meth 2009;77:41-7.

Chisti Y. Biodiesel from microalgae. Biotechnol Adv 2007;25:294-306.

Chisti Y, Yan J. Energy from algae: Current status and future trends Algal biofuels - A status report. Appl Energy 2011;88:3277-9.

John RP, Anisha GS, Nampoothiri KM, Pandey A. Micro and macroalgal biomass: A renewable source for bioethanol. Bioresour Technol 2011;102:186-93.

Johnson RA, Schmidt RR. Enzymic control of nucleic acid synthesis during synchronous growth of Chlorella pyrenoidosa. I. Deoxythymidine monophosphate kinase. Biochim Biophys Acta 1966;129:140-4.

Kaštánek F, Šabata S, Šolcová O, Maléterová Y, Kaštánek P, Brányiková I et al. In-field experimental verification of cultivation of microalgae Chlorella sp. using the flue gas from a cogeneration unit as a source of carbon dioxide. Waste Mngm Res 2010;28:961-6.

Khotimchenko SV, Yakovleva IM. Lipid composition of the red alga Tichocarpus crinitus exposed to different levels of photon irradiance. Phytochemistry 2005;66:73-9.

Klein U. Intracellular carbon partitioning in Chlamydomonas reinhardtii. Plant Physiol $1987 ; 85: 892-7$.

Klok AJ, Martens DE, Wijffels RH, Lamers PP. Simultaneous growth and neutral lipid accumulation in microalgae. Bioresour Technol 2013;134:233-43. 
Lacour T, Sciandra A, Talec A, Mayzaud P, Bernard O. Neutral lipid and carbohydrate productivities as a response to nitrogen status in Isochrysis sp. (T-iso; Haptophyceae): starvation vs. limitation. J Phycol 2012;48:647-56.

Lamers PP, Janssen M, VosR.C.H., Bino RJ, Wijffels RH. Carotenoid and fatty acid metabolism in nitrogen-starved Dunaliella salina, a unicellular green microalga. J Biotechnol 2012;162:21-7.

Levi C, Gibbs M. Starch degradation in synchronously grown Chlamydomonas reinhardtii and characterization of the amylase. Plant Physiol 1984;74:459-63.

Li X, Hu H, Zhang Y. Growth and lipid accumulation properties of a freshwater microalga Scenedesmus sp. under different cultivation temperature Bioresour Technol 2011;102:3098-102.

Li X, Přibyl P, Bišová K, Kawano S, Cepák V, Zachleder V et al. The microalga Parachlorella kessleri-a novel highly efficient lipid producer. Biotechnol Bioeng 2013;110:97-107.

Li Y, Fei X, Deng X. Novel molecular insights into nitrogen starvation-induced triacylglycerols accumulation revealed by differential gene expression analysis in green algae Micractinium pusillum. Biomass Bioenergy 2012;42:199-211.

Li Y, Han D, Hu G, Dauvillee D, Sommerfeld M, Ball S et al. Chlamydomonas starchless mutant defective in ADP-glucose pyrophosphorylase hyper-accumulates triacylglycerol. Metab Eng 2010a;12:387-91.

Li YT, Han DX, Hu GR, Sommerfeld M, Hu QA. Inhibition of starch synthesis results in overproduction of lipids in Chlamydomonas reinhardtii. Biotechnol Bioeng 2010b;107:258-68.

Lien T, Knutsen G. Phosphate as a control factor in cell division of Chlamydomonas reinhardti, studied in synchronous culture. Exp Cell Res 1973;78:79-88. 
Liu W, Huang Z, Li P, Xia J, Chen B. Formation of triacylglycerol in Nitzschia closteriumf. minutissima under nitrogen limitation and possible physiological and biochemical mechanisms. J Exp Marine Biol Ecol 2012;418:24-9.

Lv J-M, Cheng L-H, Xu X-H, Zhang L, Chen H-L. Enhanced lipid production of Chlorella vulgaris by adjustment of cultivation conditions. Bioresour Technol 2010;101:6797-804.

Mizuno Y, Sato A, Watanabe K, Hirata A, Takeshita T, Ota S et al. Sequential accumulation of starch and lipid induced by sulfur deficiency in Chlorella and Parachlorella species. Bioresour Technol 2013;129:150-5.

Moellering ER, Benning C. RNA Interference silencing of a major lipid droplet protein affects lipid droplet size in Chlamydomonas reinhardtii. Eukaryotic Cell 2010;9:97-106.

Mujtaba G, Choi W, Lee C-G, Lee K. Lipid production by Chlorella vulgaris after a shift from nutrient-rich to nitrogen starvation conditions Bioresour Technol 2012;123:279-83.

Mukherjee R, Borah S, Goswami B. Biochemical characterization of carotenoids in two species of Trentepohlia (Trentepohliales, Chlorophyta). J Appl Phycol 2010;22:569-71.

Murakami S, Morimura Y, Takamiya A. Electron microscope studies along cellular cycle in Chlorella ellipsoidea. Microalgae and Photosynthetic Bacteria (Special Issue of Plant and Cell Physiol 1963;65-83.

Nakamura Y, Takahashi J, Sakura A, Inaba Y, Suzuki E, Nihei Sea. Some cyanobacteria synthesize semi-amylopectin type $\alpha$-polyglucans instead of glycogen. Plant Cell Physiol 2005;46:539-45.

Ota M, Kato Y, Watanabe H, Watanabe M, Sato Y, Smith Jr. RL et al. Fatty acid production from a highly $\mathrm{CO}_{2}$ tolerant alga, Chlorocuccum littorale, in the presence of inorganic carbon and nitrate. Bioresour Technol 2009;100: 5237-42. 
Ota S, Matsuda T, Takeshita T, Yamazaki T, Kazama Y, Abe T et al. Phenotypic spectrum of Parachlorella kessleri (Chlorophyta) mutants produced by heavy-ion irradiation. Bioresour Technol 2013;149:432-8.

Otsuka H, Morimura Y. Change of fatty acid composition of Chlorella ellipsoidea during its cell cycle. Plant Cell Physiol 1966;7:663.

Pal D, Khozin-Goldberg I, Cohen Z, Boussiba S. The effect of light, salinity, and nitrogen availability on lipid production by Nannochloropsis sp. Appl Microbiol Biotechnol 2011;90:1429-41.

Peled E, Pick U, Zarka A, Shimoni E, Leu S, Boussiba S. Light-induced oil globule migration in Haematococcus pluvialis (Chlorophyceae). J Phycol 2012;48:1209-19.

Pruvost J, Van Vooren G, Le Gouic B, Couzinet-Mossion C, Legrand J. Systematic investigation of biomass and lipid productivity by microalgae in photobioreactors for biodiesel application. Bioresour Technol 2011;102:150-8.

Přibyl P, Cepák V, Zachleder V. Production of lipids in 10 strains of Chlorella and Parachlorella, and enhanced lipid productivity in Chlorella vulgaris. Appl Microbiol Biotechnol 2012;94:549-61.

Přibyl P, Cepák V, Zachleder V. Production of lipids and formation and mobilization of lipid bodies in Chlorella vulgaris. J Appl Phycol 2013;25:545-53.

Přibyl P, Cepák V, Zachleder V. Oil overproduction by means of microalgae. In: Bajpai RK, Prokop A, Zappi M, editors. Algal biorefineries. Dordrecht, Heidelberg, London, New York: Springer; 2014, p. 241-74.

Rabbani S, Beyer P, Lintig J, Hugueney P, Kleinig H. Induced $\beta$-carotene synthesis driven by triacylglycerol deposition in the unicellular alga Dunaliella bardawil. Plant Physiol 1998;116:1239-48. 
Ramazanov A, Ramazanov Z. Isolation and characterization of a starchless mutant of Chlorella pyrenoidosa STL-PI with a high growth rate, and high protein and polyunsaturated fatty acid content. Phycol Res 2006;54:255-9.

Ratha SK, Prasanna R, Prasad.R.B.N., Sarika C, Dhar DW, Saxena AK. Modulating lipid accumulation and composition in microalgae by biphasic nitrogen supplementation. Aquaculture 2013;392-395:69-76.

Reid RC, Prausnitz JM, Poling BE. The properties of gases and liquids. Boston: McGraw-Hill; 1987.

Rodolfi L, Zittelli GC, Bassi N, Padovani G, Biondi N, Bonini G et al. Microalgae for oil: strain selection, induction of lipid synthesis and outdoor mass cultivation in a low-cost photobioreactor. Biotechnol Bioeng 2009;102:100-12.

Roleda MY, Slocombe SP, Leakey RJG, Day JG, Bell EM, Stanley MS. Effects of temperature and nutrient regimes on biomass and lipid production by six oleaginous microalgae in batch culture employing a two-phase cultivation strategy. Bioresour Technol 2013;129:439-49.

Semenenko VE, Vladimirova MG, Opleanskaja OB, Raikov NI, Kovanova ES. Physiological characteristics of Chlorella sp. K under conditions of high extremal temperatures II. Changes in biosynthesis, ultrastructure and activity of photosynthetic apparatus of Chlorella at uncoupling cellular functions at extreme temperature. Physiol Plant (in Russ) $1969 ; 16: 210-20$.

Semenenko VE, Vladimirova MG, Orleanskaya OB. Physiological characteristics of Chlorella sp. K under conditions of high extremal temperatures I. Uncoupling effect of extreme temperatures on the cellular functions of Chlorella. Physiol Plant (in Russ) $1967 ; 14: 612-25$. 
Semenenko VE, Zvereva MG. Comparative study on the modification of photobiosynthesis direction in two Chlorella strains during decoupling of cellular functions by extreme temperature. Physiol Plant (in Russ) 1972;19:229-38.

Shibata M, Yoshimura K, Furuya N, Koike M, Ueno c, Komatsu M et al. The MAP1-LC3 conjugation system is involved in lipid droplet formation. Biochem Biophys Res Commun 2009;382:419-23.

Shibata M, Yoshimura K, Tamura H, Ueno T, Nishimura T, Inoue T et al. LC3, a microtubule-associated protein1A/B light chain3, is involved in cytoplasmic lipid droplet formation. Biochem Biophys Res Commun 2010;393:274-9.

Schmidt RR. Intracellular control of enzyme synthesis and activity during synchronous growth of Chlorella. In: Cameron IL, Padilla GM, editors. Cell Synchrony. New York, London: Academic Press; 1966, p. 189-235.

Siaut M, Cuine S, Cagnon C, Fessler B, Nguyen M, Carrier P et al. Oil accumulation in the model green alga Chlamydomonas reinhardtii: characterization, variability between common laboratory strains and relationship with starch reserves. BMC Biotechnol 2011;11:7.

Singh A, Nigam PS, Murphy JD. Mechanism and challenges in commercialisation of algal biofuels. Bioresour Technol 2011a;102:26-34.

Singh A, Nigam PS, Murphy JD. Renewable fuels from algae: An answer to debatable land based fuels. Bioresour Technol 2011b;102:10-6.

Solovchenko AE. Physiological role of neutral lipid accumulation in eukaryotic microalgae under stresses. Russ J Plant Physiol 2012;59:167-76.

Solovchenko AE, Merzlyak MN. Screening of visible and UV radiation as a photoprotective mechanism in plants Russ J Plant Physiol 2008;55:719-37. 
Sorokin C. Changes in photosynthetic activity in the course of cell development in Chlorella. Physiol Plant 1957;10:659-66.

Spoehr HA, Milner HW. The chemical composition of Chlorella: Effect of environmental conditions. Plant Physiol 1949;24:

Sukenik A. Ecophysiological considerations in the optimization of eicosapentaenoic acid production by Nannochloropsis sp. (Eustigmatophyceae). Bioresour Technol 1991;35:263-9.

Šetlík I, Ballin G, Doucha J, Zachleder V. Macromolecular syntheses and the course of cell cycle events in the chlorococcal alga Scenedesmus quadricauda under nutrient starvation: Effect of sulphur starvation. Biol Plantarum 1988;30:161-9.

Šetlík I, Berková E, Doucha J, Kubín S, Vendlová J, Zachleder V. The coupling of synthetic and reproduction processes in Scenedesmus quadricauda. Arch Hydrobiol/Suppl 41, Algolog Stud 1972;7:172-217.

Šetlík I, Zachleder V. The multiple fission cell reproductive patterns in algae. In: Nurse P, Streiblová E, editors. The microbial cell cycle. Boca Raton, Florida, USA: CRC Press Inc.; 1984, p. 253-79.

Takeshita T, Ota S, Yamazaki T, Hirata A, Zachleder V, Kawano S. Starch and lipid accumulation in eight strains of six Chlorella species under comparatively high light intensity and aeration culture conditions. Bioresour Technol 2014;127-134158:127-34.

Tamiya H. Growth and cell division of Chlorella. In: Zeuthen E, editors. Synchrony in cell division and growth. New York-London-Sydney: Wiley, J.Z. Sons Inc.; 1964, p. 247-305.

Tanadul O, VanderGheynst JS, Beckles DM, Powell ALT, Labavitch JM. The impact of elevated $\mathrm{CO}_{2}$ concentration on the quality of algal starch as a potential biofuel feedstock. Biotechnol Bioeng 2014;111:1323-31. 
van den Hoek C, Mann DG, Jahns HM. Algae, an introduction to phycology. Cambridge: Cambridge University Press; 1995.

Vigeolas H, Duby F, Kaymak E, Niessen G, Motte P, Franck F et al. Isolation and partial characterization of mutants with elevated lipid content in Chlorella sorokiniana and Scenedesmus obliquus. J Biotechnol 2012;162:3-12.

Vítová M, Bišová K, Hlavová M, Zachleder V, Rucki M, Čížková M. Glutathione peroxidase activity in the selenium-treated alga Scenedesmus quadricauda. Aquat Toxicol 2011a;102:87-94.

Vítová M, Bišová K, Umysová D, Hlavová M, Kawano S, Zachleder V et al. Chlamydomonas reinhardtii: duration of its cell cycle and phases at growth rates affected by light intensity. Planta 2011b;233:75-86.

Vítová M, Zachleder V. Points of commitment to reproductive events as a tool for analysis of the cell cycle in synchronous cultures of algae. Folia Microbiol 2005;50:141-9.

Wang ZT, Ullrich N, Joo S, Waffenschmidt S, Goodenough U. Algal lipid bodies: stress induction, purification, and biochemical characterization in wild-type and starchless Chlamydomonas reinhardtii. Eukar Cell 2009;8:1856-68.

Wanka F, Joppen MMJ, Kuyper CMA. Starch degrading enzymes in synchronous cultures of Chlorella. Z Planzenphysiol 1970;62:146-57.

Wayama M, Ota S, Matsuura H, Nango N, Hirata A, Kawano S. Three-dimensional ultrastructural study of oil and astaxanthin accumulation during encystment in the green alga Haematococcus pluvialis. PLoS One 2013;8:e53618.

Work VH, Radakovits R, Jinkerson RE, Meuser JE, Elliott LG, Vinyard DJ et al. Increased lipid accumulation in the Chlamydomonas reinhardtii sta7-10 starchless isoamylase mutant and increased carbohydrate synthesis in complemented strains. Eukar Cell 2010;9:1251-61. 
Wu Y-H, Yu Y, Hu H-Y. Potential biomass yield per phosphorus and lipid accumulation property of seven microalgal species. Bioresour Technol 2013;130:599-602.

Xia S, Gao B, Li A, Xiong J, Ao Z, Zhang C. Preliminary characterization, antioxidant properties and production of chrysolaminarin from marine diatom Odontella aurita. Mar Drugs 2014;12:4883-97.

Yang H, Galea A, Sytnyk V, Crossley M. Controlling the size of lipid droplets: lipid and protein factors. Curr Op Cell Biol 2012;24:509-16.

Yang Z-K, Niu Y-F, Ma Y-H, Xue J, Zhang M-H, Yang W-D et al. Molecular and cellular mechanisms of neutral lipid accumulation in diatom following nitrogen deprivation Biotechnol Biofuels 2013;6:1-14.

Yao C-H, Ai J-N, Cao Z-P, Xue S. Characterization of cell growth and starch production in the marine green microalga Tetraselmis subcordiformis under extracellular phosphorusdeprived and sequentially phosphorus-replete conditions. Appl Microbiol Biotechnol 2013;97:6099-110.

Yao C, Ai J, Cao X, Xue S, Zhang W. Enhancing starch production of a marine green microalga Tetraselmis subcordiformis through nutrient limitation. Bioresour Technol 2012;118:438-44.

Zabawinski C, Van Den Koornhuyse N, D'Hulst C, Schlichting R, Giersch C, Delrue B et al. Starchless mutants of Chlamydomonas reinhardtii lack the small subunit of a heterotetrameric ADP-glucose pyrophosphorylase. J Bacteriol 2001;183:1069-77.

Zachleder V. The effect of hydroxyurea and fluorodeoxyuridine on cell cycle events in the chlorococcal alga Scenedesmus quadricauda (Chlorophyta). J Phycol 1994;30:274-9.

Zachleder V. Regulation of growth processes during the cell cycle of the chlorococcal alga Scenedesmus quadricauda under a DNA replication block. J Phycol 1995;30:941-7. 
Zachleder V, Ballin G, Doucha J, Šetlík I. Macromolecular syntheses and the course of cell cycle events in the chlorococcal alga Scenedesmus quadricauda under nutrient starvation: Effect of phosphorus starvation. Biol Plantarum 1988;30:92-9.

Zachleder V, Bišová K, Vítová M, Kubín Š, Hendrychová J. Variety of cell cycle patterns in the alga Scenedesmus quadricauda (Chlorophyta) as revealed by application of illumination regimes and inhibitors. Eur J Phycol 2002;37:361-71.

Zachleder V, Brányiková I. Starch overproduction by means of algae. In: Bajpai RK, Prokop A, Zappi M, editors. Algal biorefineries. Dordrecht, Heidelberg, London, New York: Springer; 2014, p. 217-40.

Zachleder V, Kawano S, Kuroiwa T. Uncoupling of chloroplast reproductive events from cell cycle division processes by 5-fluorodeoxyuridine in the alga Scenedesmus quadricauda. Protoplasma 1996;192:228-34.

Zachleder V, Šetlík I. Distinct controls of DNA-replication and of nuclear division in the cellcycles of the chlorococcal alga Scenedesmus quadricauda. J Cell Sci 1988;91:531-9.

Zachleder V, Šetlík I. Timing of events in overlapping cell reproductive sequences and their mutual interactions in the alga Scenedesmus quadricauda. J Cell Sci 1990;97:631-8.

Zachleder V, van den Ende H. Cell cycle events in the green alga Chlamydomonas eugametos and their control by environmental factors. J Cell Sci 1992;102:469-74.

Zhang L, Happe T, Melis A. Biochemical and morphological characterization of sulfurdeprived and H2-producing Chlamydomonas reinhardtii (green alga). Planta 2002;214:552-61.

Zhao G, Yu J, Jiang F, Zhang X, Tan T. The effect of different trophic modes on lipid accumulation of Scenedesmus quadricauda. Bioresour Technol 2012;114:466-71. 
Zheng Y, Chen Z, Lu H, Zhang W. Optimization of carbon dioxide fixation and starch accumulation by Tetraselmis subcordiformis in a rectangular airlift photobioreactor. Afr J Biotechnol 2011;10:1888-901.

Zukova TS, Klyachko-Gurvich GS, Vladimirova MG, Kurnosova AT. Comparative characterisation of the growth and direction of biosynthesis of various strains of Chlorella under conditions of nitrogen starvation. II. Formation of carbohydrates and lipids. Plant Physiol (in Russ) 1969;16:79-83. 


\section{Figure captions}

Fig. 1. Simplified triacylglycerol and starch metabolism in green microalgae. The dashed lines are reactions that take place in the cytosol. Two possible ways for the formation of TAG molecules are shown following the postulated route in the chloroplasts or over the ER membranes in the cytosol. 3PG, 3-phosphoglycerate; ER, endoplasmic reticulum; TAG, triacylglycerol (de van Jaeger et al., 2013)

Fig. 2. Electron microscopic photographs of daughter (A) and mother (B) cells of Chlorella vulgaris grown in complete mineral medium, in the presence of cycloheximide $\left(1 \mathrm{mg} \mathrm{L}^{-1}\right)$ (C), and in sulfur limiting medium (D). N, nucleus; $\mathbf{S}$, starch granules. Bars panels A-C: $2 \mu \mathrm{m}$; bar panel D: $5 \mu \mathrm{m}$. (Brányiková et al., 2011)

Fig. 3. Changes in biomass concentration (DW in $\left.\mathrm{g} \mathrm{L}^{-1}\right)$, starch content $\left(\mathrm{g} \mathrm{L}^{-1}\right)(\mathbf{A})$, and relative starch content (\% of DW) (B) in cultures of Chlorella vulgaris. The cultures were grown in an outdoor scaled-up thin-layer photobioreactor in complete mineral medium for $96 \mathrm{~h}$ and then in sulfur limited medium (-S). Dark periods (nights) are marked by black stripes and separated by vertical solid lines. Linear regression curves of the 1 st order (solid lines) were fitted to the experimental data separately for the periods of culture grown in complete medium and sulfur-limited cultivation. (Brányiková et al., 2011)

Fig. 4. Time course of lipid accumulation during batch cultivation of Parachlorella kessleri. Lipid bodies were stained using Nile Red (yellow); autofluorescence of chloroplasts is seen in red. Cultures were grown in complete mineral medium (1 medium), or in either nitrogen (-N), phosphorus (-P) or sulfur (-S) free media. The cultivation time for all variants is indicated in the left column. The same initial biomass concentration $\left(0.3 \mathrm{~g} \mathrm{~L}^{-1}\right)$ was used for all cultures and no detectable lipid bodies were seen in cells at the beginning (0 h; not shown in figure). Scale bar $=10 \mu \mathrm{m}$. (Li et al. 2011) 
Figure 1

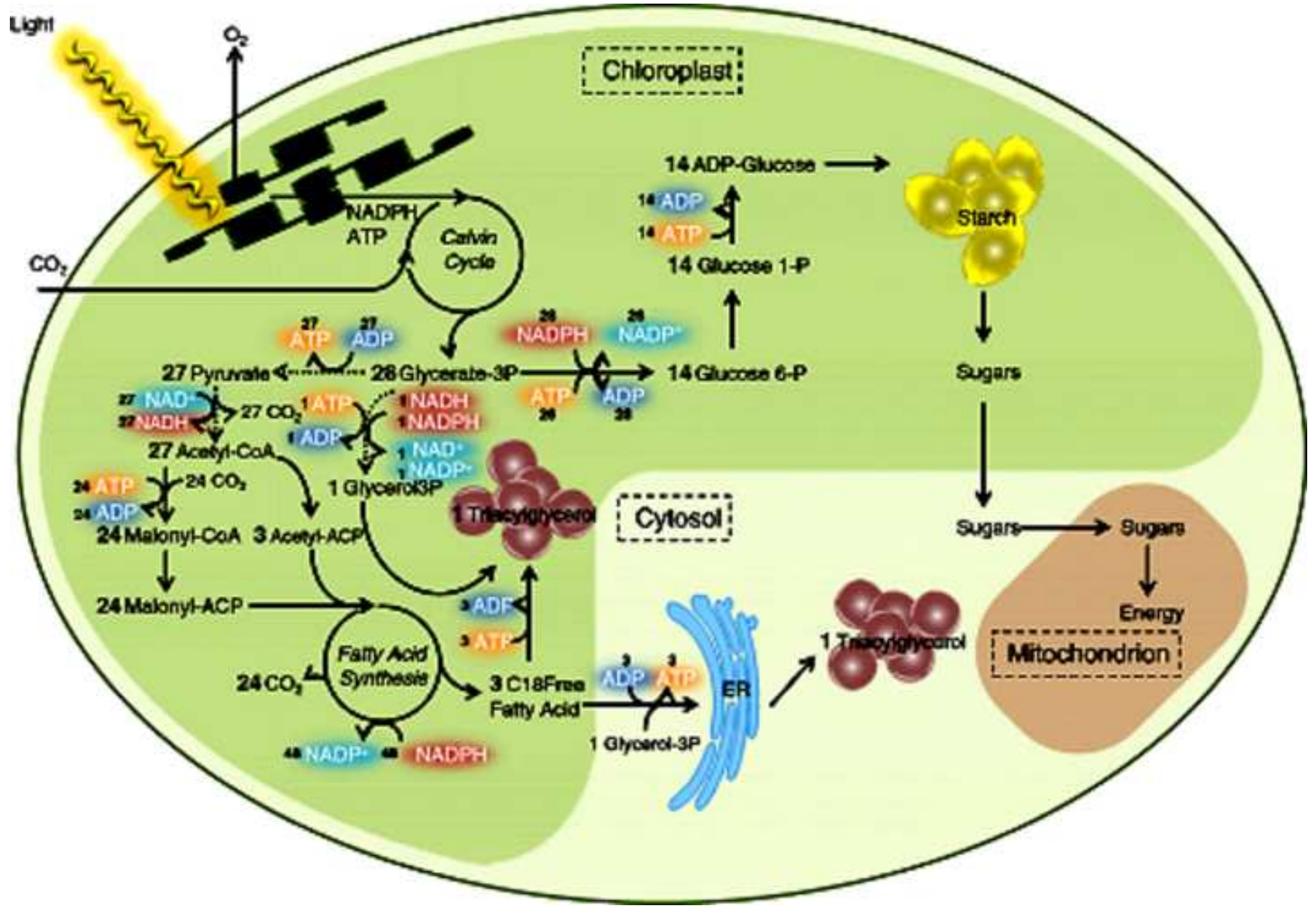



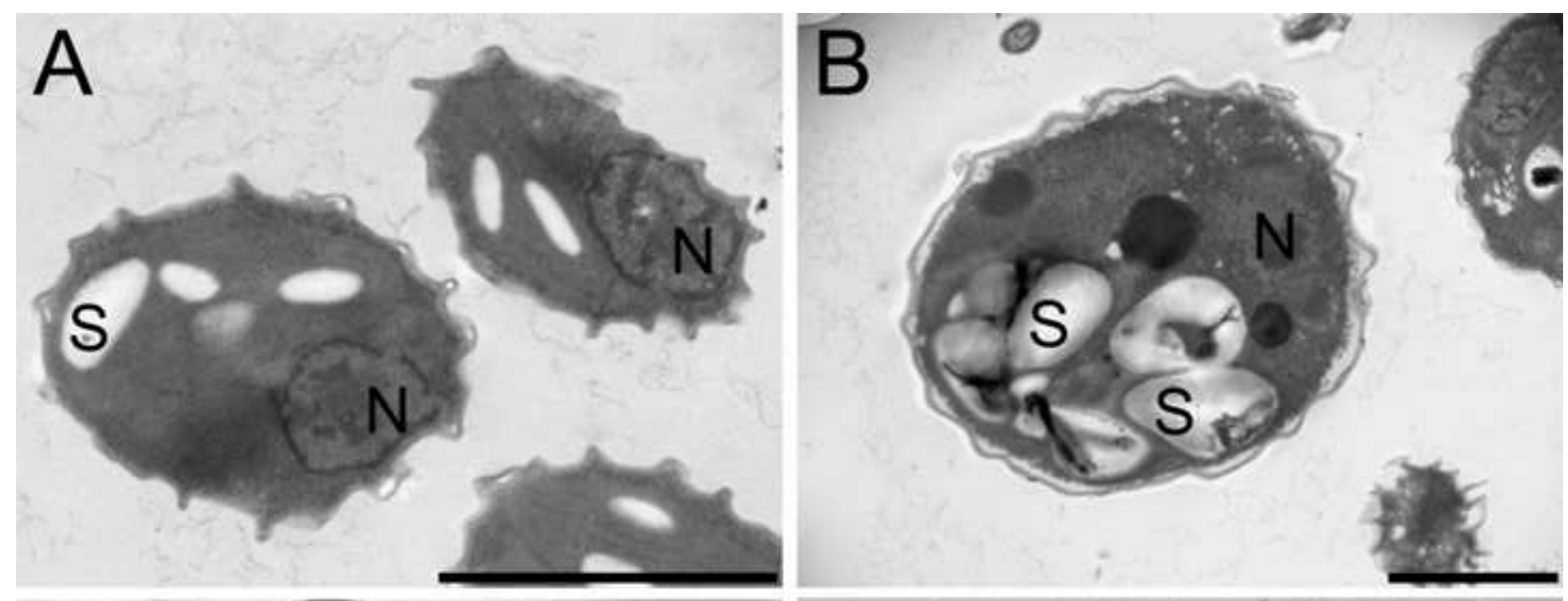

C
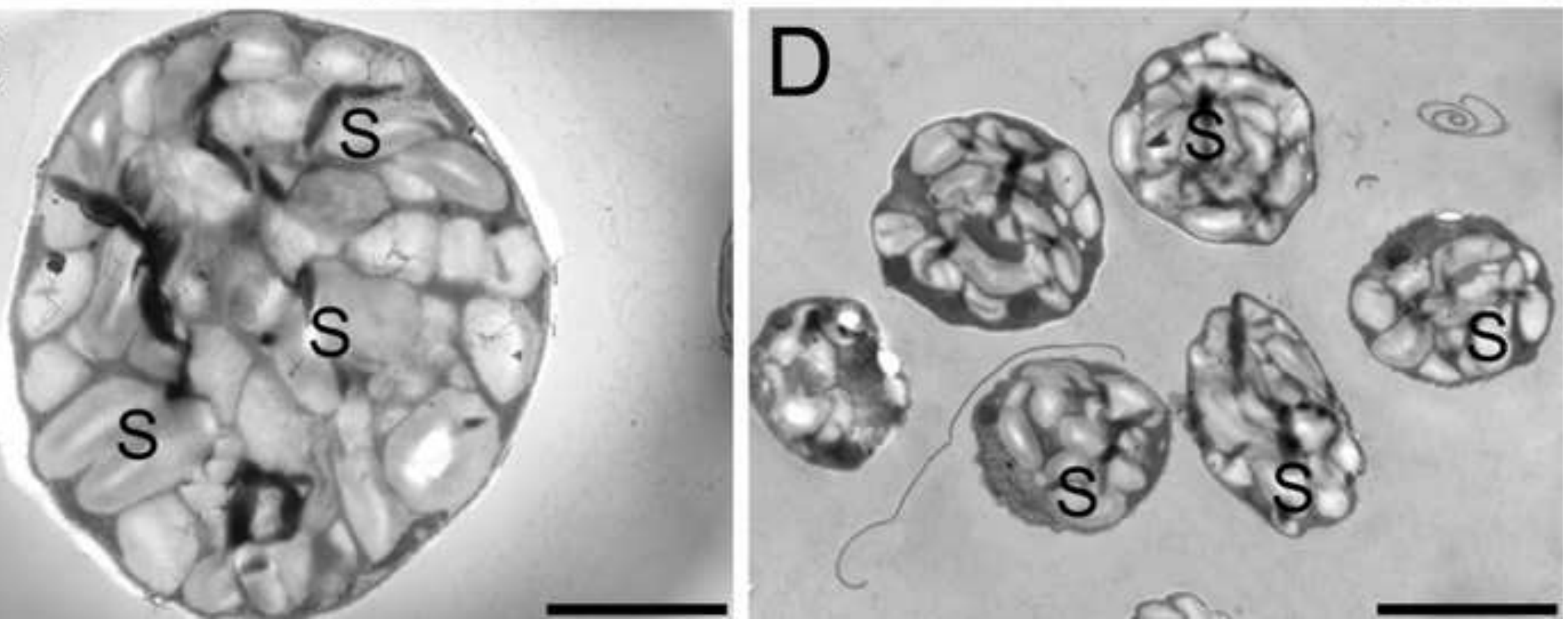

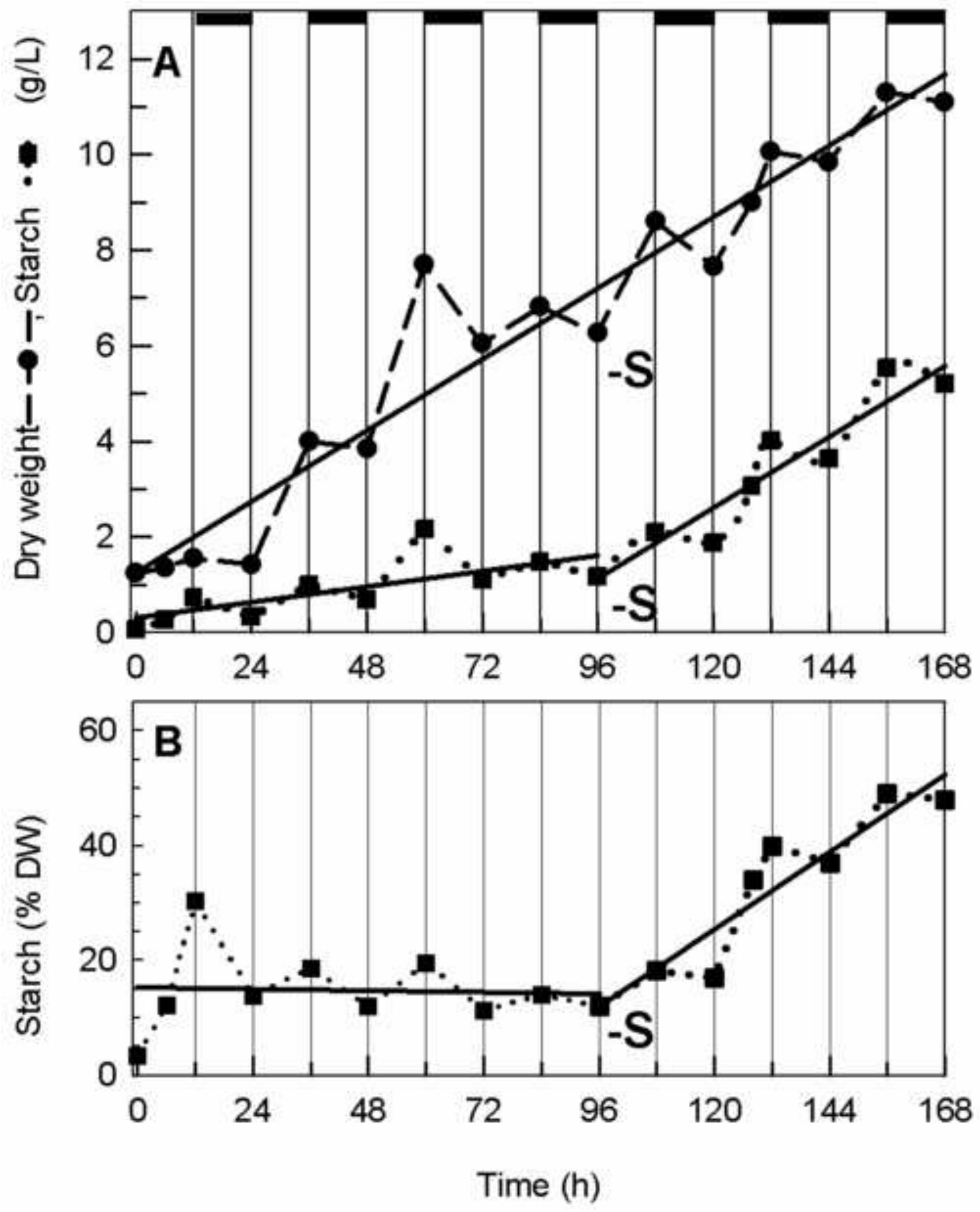


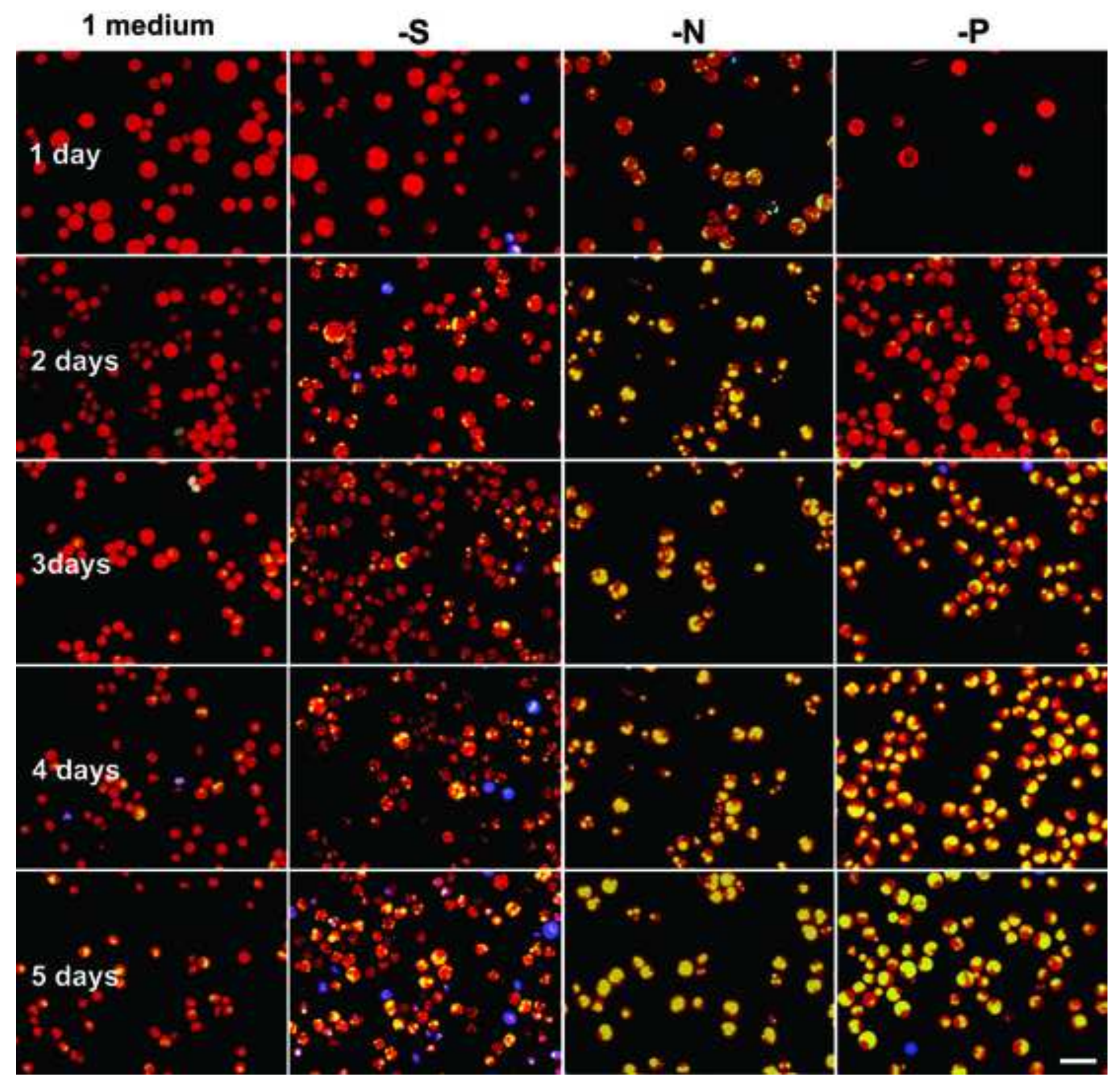

